\title{
Pharmacophore Identification and Scaffold Exploration to Discover Novel, Potent, and Chemically Stable Inhibitors of Acid Ceramidase in Melanoma Cells
}

Jose Antonio Ortega, ${ }^{\dagger, \#}$ Jose M. Arencibia, ${ }^{\dagger, \#}$ Giuseppina La Sala, ${ }^{\dagger}$ Marco Borgogno, ${ }^{\dagger}$ Inga Bauer, ${ }^{\|}$ Luca Bono, ${ }^{\S}$ Clarissa Braccia, ${ }^{\S}$ Andrea Armirotti, ${ }^{\S}$ Stefania Girotto," Anand Ganesan, ${ }^{\perp}$ and Marco De Vivo*, $*$,

${ }^{\dagger}$ Laboratory of Molecular Modeling \& Drug Discovery, Istituto Italiano di Tecnologia, Via Morego 30, 16163 Genoa, Italy

${ }^{\ddagger}$ IAS-5/INM-9 Computational Biomedicine Forschungszentrum Jülich, Wilhelm-Johnen-Straße, 52428 Jülich, Germany

${ }^{\S}$ D3-PharmaChemistry, Istituto Italiano di Tecnologia, Via Morego 30, 16163 Genoa, Italy

"CompuNet, Istituto Italiano di Tecnologia, Via Morego 30, 16163 Genoa, Italy

${ }^{\perp}$ Department of Dermatology and Biological Chemistry, University of California, 202 Sprague Hall, 92697-2400 Irvine, United States

Supporting Information

ABSTRACT: Acid ceramidase (AC) hydrolyzes ceramides, which are central lipid messengers for metabolism and signaling of sphingolipids. A growing body of evidence links deregulation of sphingolipids to several diseases, including cancer. Indeed, AC expression is abnormally high in melanoma cells. AC inhibition may thus be key to treating malignant melanoma. Here, we have used a systematic scaffold exploration to design a general pharmacophore for AC inhibition. This pharmacophore comprises a $6+5$ fused ring heterocycle linked to an aliphatic substituent via a urea moiety. We have thus identified the novel benzimidazole derivatives 10, 21, 27, and 30, which are highly potent AC inhibitors. Their chemical and metabolic stabilities are

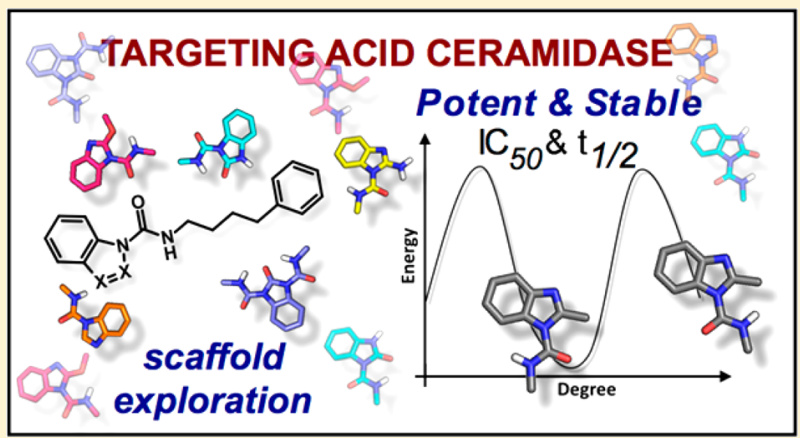
comparable or superior to those of previously reported AC inhibitors. Moreover, they are potent against endogenous AC in intact melanoma cells. These novel inhibitors merit further characterization and can serve as a promising starting point for the discovery of new antimelanoma therapeutics.

\section{INTRODUCTION}

The incidence of cutaneous melanoma continues to rise. ${ }^{1,2}$ At the same time, treating unresectable or metastatic melanoma with conventional cytotoxic agents (such as dacarbazine) has failed to produce the expected survival benefit. ${ }^{3}$ The survival of patients with advanced melanoma has been increased by using BRAF and MEK inhibitors and by using antibodies that block immune-checkpoint molecules (such as ipilimumab, which targets the cytotoxic T lymphocyte antigen 4 (CTLA-4)). ${ }^{4-6}$ Nevertheless, progression of melanoma due to intrinsic and/or acquired resistance to these novel treatments remains a major issue. ${ }^{7}$ In addition, clinicians are concerned about the toxicity, tolerability, and effectiveness of these new agents. ${ }^{8}$ Combination therapy is an alternative and promising approach, where novel targeted agents and traditional anticancer modalities (radiation, chemotherapy, or surgery) are used together to enhance treatment efficacy and reduce side-effects. ${ }^{9}$ Combination therapy, however, has not yet demonstrated a significant decrease in the mortality of melanoma patients. For all these reasons, treatment of advanced melanoma is still an unmet medical need, ${ }^{6}$ and novel therapeutic strategies are urgently required. ${ }^{1}$

Recent findings have shown that the acid ceramidase (AC) enzyme may be a novel target for treating several types of cancer, including melanoma. ${ }^{10-12} \mathrm{AC}$ is a cysteine amidase that hydrolyzes the proapoptotic lipid-derived messenger ceramide, a central molecule in sphingolipid metabolism and signaling. ${ }^{13-15}$ The expression of AC is abnormally high in several tumors, suggesting that the dysregulation of ceramide metabolism could be linked to cancer development and progression. ${ }^{16-18}$ Indeed, AC overexpression has been detected in various types of human cancer (e.g., melanoma, head and neck, prostate, and colon cancer). Moreover, autoantibodies against $\mathrm{AC}$ have been found in the serum of melanoma patients, suggesting that $\mathrm{AC}$ might also be used as a biomarker for disease prognosis. ${ }^{19}$ There is also evidence that overexpression of AC may be related to higher resistance to pharmacological induction of apoptosis, ${ }^{20,21}$ while AC inhib-

Received: March 31, 2017

Published: June 12, 2017 


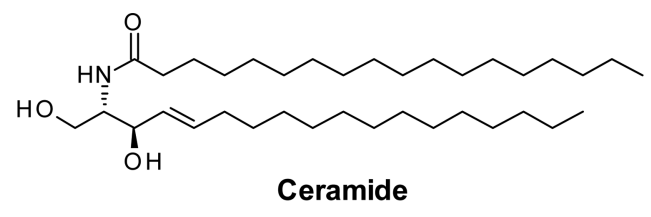

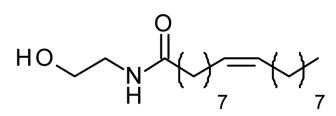

N-Oleoylethanolamine (NOE)<smiles>CCCCCCCCCC(=O)NC(C)Cc1ccccc1</smiles>

(1S,2R)-N-myristoylaminophenylpropanol-1 (D-e-MAPP)<smiles>[R]c1ccc2[nH]c(=O)c(C(=O)/C=C/c3ccc(OC)cc3)c(-c3ccccc3)c2c1</smiles>

Ceranib 1, $\mathrm{R}=\mathrm{Me}$ Ceranib 2, R= H<smiles>[R]c1ccc2c(c1)oc(=O)n2C(=O)NCCCCc1ccccc1</smiles>

Benzoxazolone 1, $\mathrm{R}=\mathrm{H}, \mathrm{IC}_{50} 64 \mathrm{nM}, \mathrm{t}_{1 / 2}(\mathrm{pH} 7.4) 45 \mathrm{~min}, \mathrm{t}_{1 / 2}$ (mouse plasma) $60 \mathrm{~min}$ Benzoxazolone 2, $\mathrm{R}=\mathrm{Br}, \mathrm{IC}_{50} 32 \mathrm{nM}, \mathrm{t}_{1 / 2}\left(\mathrm{pH} \mathrm{7.4)} 24 \mathrm{~min}, \mathrm{t}_{1 / 2}\right.$ (mouse plasma) $8 \mathrm{~min}$

Benzoxazolone 3, $\mathrm{R}=p-\mathrm{F}-\mathrm{Ph}, \mathrm{IC}_{50} 79 \mathrm{nM}, \mathrm{t}_{1 / 2}(\mathrm{pH} 7.4)>300 \mathrm{~min}, \mathrm{t}_{1 / 2}$ (mouse plasma) $>120 \mathrm{~min}$

Figure 1. Ceramide and known acid ceramidase (AC) inhibitors.

ition sensitizes cancer cells to the action of anticancer therapeutics. $^{20,22}$ Taken together, there is a growing body of evidence that indicates $\mathrm{AC}$ inhibition as an effective and innovative therapeutic approach to treat melanoma, as well as other cancers. ${ }^{10,23-25}$

In the last two decades, a few potent $\mathrm{AC}$ inhibitors have been discovered. $^{26,27}$ Initially, inhibitors such as $\mathrm{NOE}^{28}$ and D-e$\mathrm{MAPP}^{29}$ were designed for their similarity to ceramide, the endogenous AC ligand (Figure 1). However, these inhibitors have low potency and selectivity, being also active against $\mathrm{Cz}$ ceramide-activated phosphatase (CAPP) and protein kinase $\mathrm{C}$ (PKC). Optimization of these first-generation inhibitors led to slightly better activity in vitro and in vivo (ceranib 1 and 2, see Figure 1). ${ }^{23,26}$ Recently, however, more potent ceramideunrelated inhibitors of $\mathrm{AC}$ have been identified by synthesizing new derivatives of 5-fluorouracil (5-FU) and by screening commercial chemical libraries, which returned promising AC blockers such as the benzoxazolone carboxamide compounds. ${ }^{30-32}$ These inhibitors are fairly potent, being active in the nanomolar range (see benzoxazolone 1,2 , and 3 in Figure 1). This class of inhibitors blocks AC by forming a covalent adduct with the catalytic Cys-143. This covalent ligand-target interaction is due to the presence of a urea group in the benzoxazolone carboxamide derivatives. The urea is cleaved to generate the covalent $\mathrm{AC}$-inhibitor complex. ${ }^{33}$ Although promising, these benzoxazolone carboxamides derivatives suffer from limited stability, which may hinder their development as clinically viable therapeutic agents.

Here, we report on an extensive exploration of different scaffolds that act by covalently inhibiting AC, just like their template benzoxazolone carboxamide derivatives. Our goal was to understand which chemical features are necessary for potent AC inhibition while improving chemical stability. Thus, we present a general pharmacophore for $\mathrm{AC}$ inhibition that combines $6+5$ fused ring heterocycles with different aliphatic chains, linked via a urea functional group (Figure 2). We obtained a set of 30 new compounds, with seven different

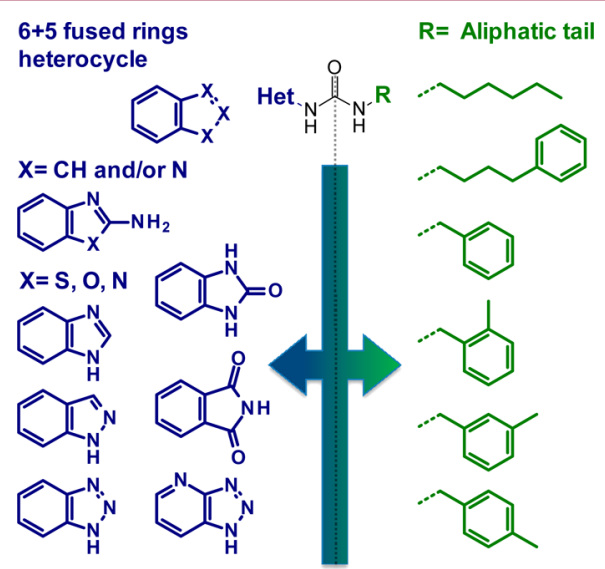

Figure 2. Proposed pharmacophore for AC covalent inhibitors.

chemical cores. The four most potent and stable AC inhibitors 10, 21, 27, and 30 also inhibited AC in intact cells. This information will be useful for further optimizing these promising compounds.

\section{RESULTS AND DISCUSSION}

Strategy for Pharmacophore Exploration. Previous studies described a set of potent but only fairly stable benzoxazolone inhibitors of the AC enzyme (Figure 1). These were all characterized by the presence of the urea functional group, which was demonstrated to be crucial for activity against AC. These potent compounds are active in the low nanomolar range, acting by forming an adduct with the nucleophilic Cys-143 residue of $\mathrm{AC}^{33}$ Notably, all these covalent inhibitors are characterized by an aliphatic substituent, 
Table 1. Synthesized Compounds

\begin{tabular}{|c|c|c|c|}
\hline Cpd & Heterocycle & $\mathbf{R}$ & Yield \\
\hline 1 & & Hexyl & $64 \%$ \\
\hline 2 & & 4-phenylbutyl & $85 \%$ \\
\hline 3 & & Hexyl & $64 \%$ \\
\hline 4 & & 4-phenylbutyl & $57 \%$ \\
\hline 5 & & Hexyl & $70 \%$ \\
\hline 6 & & 4-phenylbutyl & $70 \%$ \\
\hline 7 & & Hexyl & $64 \%$ \\
\hline 8 & & 4-phenylbutyl & $64 \%$ \\
\hline 9 & & Hexyl & $20 \%$ \\
\hline 10 & & 4-phenylbutyl & $43 \%$ \\
\hline 11 & & Hexyl & $70 \%$ \\
\hline 12 & & 4-phenylbutyl & $61 \%$ \\
\hline 13 & & Hexyl & $64 \%$ \\
\hline 14 & & 4-phenylbutyl & $64 \%$ \\
\hline 15 & & Hexyl & $61 \%$ \\
\hline 16 & & 4-phenylbutyl & $62 \%$ \\
\hline
\end{tabular}

which mimics the alkylic tail of the AC natural substrate, and which is linked through the urea functional group to the benzoxazolone heterocyclic core. ${ }^{34}$

In an effort to elucidate and improve the pharmacological shortcomings of the existing covalent inhibitors of $\mathrm{AC}$, we explored the chemistry of a general pharmacophore for AC inhibition. This was designed by combining $6+5$ fused ring heterocycles and different aliphatic tails (Figure 2). Seven different $6+5$ fused ring heterocycles (benzothiazole, benzoxazole, benzimidazole, indazole, benzotriazole, 4-azabenzotriazole, and phathalimide) were combined via a urea functional group to different aliphatic tails. In this way, these seven different cores were linked to both hexyl- and 4phenylbutyl fragment tails, which were selected from previous inhibition studies ${ }^{31-34}$ (Figure 2), obtaining an initial set of 18 compounds. In addition, we synthesized a set of four 2benzimidazole derivatives to study the effect of these modifications on potency and stability. We also considered a benzyl-containing tail, generating eight additional compounds, for a total of 30 new derivatives that block the targeted $\mathrm{AC}$ enzyme (Table 1).

First, we investigated how the presence of either an exocyclic or endocyclic urea linked to each different compound core

\begin{tabular}{|c|c|c|c|}
\hline Cpd & Heterocycle & $\mathbf{R}$ & Yield \\
\hline 17 & & Hexyl & $38 \%$ \\
\hline 18 & & 4-phenylbutyl & $12 \%$ \\
\hline 19 & & 4-phenylbutyl & $23 \%$ \\
\hline 20 & & 4-phenylbutyl & $56 \%$ \\
\hline 21 & & 4-phenylbutyl & $45 \%$ \\
\hline 22 & & 4-phenylbutyl & $57 \%$ \\
\hline 23 & & Benzyl & $64 \%$ \\
\hline 24 & & 2-Methylbenzyl & $64 \%$ \\
\hline 25 & & 3-Methylbenzyl & $35 \%$ \\
\hline 26 & & 4-Methylbenzyl & $60 \%$ \\
\hline 27 & & Benzyl & $56 \%$ \\
\hline 28 & & 2-Methylbenzyl & $66 \%$ \\
\hline 29 & & 3-Methylbenzyl & $68 \%$ \\
\hline 30 & & 4-Methylbenzyl & $66 \%$ \\
\hline
\end{tabular}

affects their inhibitory activity against AC. We used either 2aminobenzothiazole or 2-aminobenzoxazole to synthesize an initial set of four derivatives containing the exocyclic urea (1-4 in Table 1). Notably, these compounds only have an exocyclic amino group accessible for chemical synthesis. Then, four additional derivatives were synthesized from 2-aminobenzimidazole, where both endocyclic and exocyclic amino groups could be derivatized (5-8 in Table 1$)$. In a second step, after identifying endocyclic ureas as the most active ones, we synthesized a group of 10 compounds bearing different heterocycles and both hexyl- and 4-phenylbutyl tails (9-18 in Table 1). In addition, we synthesized a third set of four compounds containing the 4-phenylbutyl fragment tail, which produced the best inhibitory results against AC, and different 2substituted benzimidazoles. Finally, we synthesized a group of eight compounds containing a benzyl group with a single methyl substituent at different positions along the aliphatic fragment, as an alternative tail. Encouraged by the results obtained with compounds bearing the 4-phenylbutyl tail, which resulted in more potent inhibitors, we investigated additional tails formed by combining an aromatic group with an alkyl fragment. 
Chemistry. The synthesis of all the differently substituted ureas was efficiently accomplished by a general strategy, which involved reacting different heterocycle cores (Het, see Table 1) with an appropriate isocyanate in the presence of a catalytic amount of 4-(dimethylamino)pyridine (DMAP) (Scheme 1).

Scheme 1. General Pathway for Urea Synthesis ${ }^{a}$

$$
\begin{aligned}
& \mathrm{Het}+\mathrm{R}-\mathrm{NCO} \stackrel{\mathrm{i}}{\longrightarrow} \text { Het. }_{\mathrm{H}} \mathrm{H}_{\mathrm{H}^{-}}^{\mathrm{O}} \\
& \text { 1-4, 7-30 }
\end{aligned}
$$

${ }^{a}$ Reagents and conditions: (i) DMAP (0.1 equiv), pyridine, $\mathrm{N}_{2}$, room temperature, $5 \mathrm{~h}$.

All heterocycles were commercially available, with the exception of 2-methoxy-1H-benzimidazole, which was synthesized following an adapted procedure from a previously described protocol (Scheme 2). ${ }^{35}$

Scheme 2. Synthesis of 2-Methoxy-1H-benzimidazole ${ }^{a}$

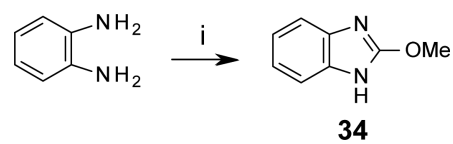

${ }^{a}$ Reagents and conditions: (i) tetramethylortho carbonate (1.4 equiv), $\mathrm{Ar}, 90^{\circ} \mathrm{C}, 24 \mathrm{~h}$

Compounds 1-4 and 7-30 were obtained in moderate to good yields as indicated in the Supporting Information. The reaction with heterocycles 2-aminobenzimidazole $(7,8)$ and with $1 H$-1,2,3-triazolo[4,5- $b]$ pyridine $(\mathbf{1 5 , 1 6})$ was regioselective, as previously described. ${ }^{36,37}$ Compounds 19 and 20 were obtained by adding one or two equivalents of the corresponding isocyanate, respectively.

Compounds 5 and $\mathbf{6}$ bear a urea in the exocyclic amino group attached to the 2 -aminobenzimidazole. They were obtained via an alternative strategy (Scheme 3). The heterocycle was first selectively protected on $\mathrm{N} 1$ with a tert-butyl carbamoyl group, adapting a known procedure. ${ }^{38}$ Then, intermediate 31 permitted regioselective urea formation on the 2-amino group with both hexyl and 4-phenylbutyl isocyanates, in the presence of catalytic DMAP at $80{ }^{\circ} \mathrm{C}$. Finally, elimination of the protecting group in pyridine was achieved by heating at $80^{\circ} \mathrm{C}$, yielding the 2 -amino derivatives 5 and 6.

Structure-Activity Relationships. For the first set of compounds, those bearing endocyclic ureas are more active than exocyclic ones (Table 2). Compounds 1-6, which all have the urea fragment linked to the exocyclic 2 -amino group, were
Table 2. Exocyclic Amine Ureas versus Endocyclic Amine Ureas

\begin{tabular}{|c|c|c|c|}
\hline Cpd & Het & $\mathbf{R}$ & $\mathrm{IC}_{50}(\mathrm{nM})^{\mathrm{a}}$ \\
\hline Carmofur & & & $20.7 \pm 4.1$ \\
\hline 1 & & & $>10000$ \\
\hline 2 & & & $>10000$ \\
\hline 3 & & & $>10000$ \\
\hline 4 & & & $>10000$ \\
\hline 5 & & & $>10000$ \\
\hline 6 & & & $>10000$ \\
\hline 7 & & & $2.4 \pm 1.1$ \\
\hline 8 & & & $0.9 \pm 0.2$ \\
\hline
\end{tabular}

$$
\text { Het }{ }_{H}{ }_{\mathrm{H}^{-}}^{\mathrm{O}}
$$

${ }^{a} \mathrm{IC}_{50}$ values are reported as mean $\pm \mathrm{SD}$ values of three determinations.

inactive (at the highest concentration tested), whereas compounds 7 and 8 , which present the same type of substitution in the endocyclic $\mathrm{N} 1$, displayed potent $\mathrm{AC}$ inhibition ( $\mathrm{IC}_{50} 2.4 \mathrm{nM}$ and $0.9 \mathrm{nM}$, respectively).

On the basis of this evidence, we focused on those heterocycles bearing endocyclic ureas. Four more $6+5$ fused ring heterocycles with an endocyclic amino group were used to synthesize new derivatives with either a hexyl or a 4phenylbutyl group (compounds 9-18, Table 3).

Interestingly, all of the considered heterocycles generated potent AC inhibitors. All of the compounds bearing the same aliphatic tail can be considered equipotent, suggesting that a $6+$ 5 fused ring heterocycle anchored by an endocyclic amino group is sufficient for AC inhibition. Larger differences were observed when comparing both aliphatic tails. In all cases, compounds bearing the 4-phenylbutyl tail returned an $\mathrm{IC}_{50}$ value that was on average twice as potent as those bearing the hexyl tail. Notably, the presence of a phenyl group in the aliphatic tail of the molecules provided an advantage in terms of AC inhibition. This slight improvement in potency may be due

Scheme 3. Synthesis of 2-Aminobenzimidazole Exocyclic Ureas 5 and $6^{a}$

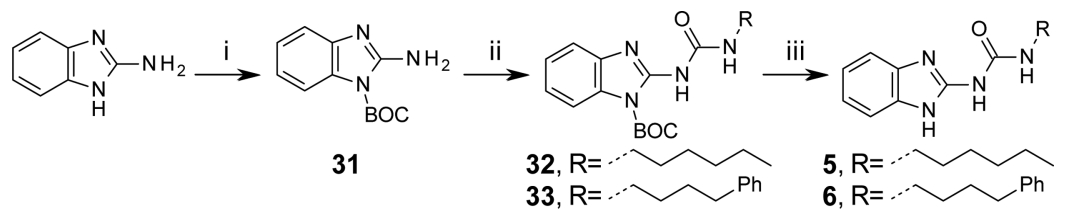

${ }^{a}$ Reagents and conditions: (i) $\mathrm{Boc}_{2} \mathrm{O}$ (1 equiv), $\mathrm{Et}_{3} \mathrm{~N}$ ( 3 equiv), THF (dry), room temperature, 5 h, yield 95\%. (ii) R-NCO (1 equiv), DMAP (0.1 equiv), pyridine, $\mathrm{N}_{2}, 80^{\circ} \mathrm{C}, 3 \mathrm{~h}$. For $\mathrm{R}=$ hexyl yield $11 \%$. For $\mathrm{R}=4$-phenylbutyl yield $12 \%$. (iii) Pyridine, $80{ }^{\circ} \mathrm{C}, 16 \mathrm{~h}$. For $\mathrm{R}=$ hexyl yield $70 \%$. For $\mathrm{R}=$ 4-phenylbutyl yield $70 \%$. 
Table 3. Exploration of $5+6$ Fused Ring Heterocycles

\begin{tabular}{|c|c|c|c|c|c|c|}
\hline \multirow{2}{*}{ Cpd } & \multirow{2}{*}{ Het } & \multirow[b]{2}{*}{$\mathbf{R}$} & \multirow{2}{*}{$\begin{array}{c}\mathrm{IC}_{50} \\
(\mathrm{nM})^{\mathrm{a}}\end{array}$} & \multicolumn{3}{|c|}{ Stability $t_{1 / 2}(\min )$} \\
\hline & & & & $\begin{array}{l}\text { Buffer } \\
\text { pH } 4.5\end{array}$ & $\begin{array}{l}\text { Buffer } \\
\text { pH } 7.4\end{array}$ & $\begin{array}{l}\text { Mouse } \\
\text { plasma }\end{array}$ \\
\hline 9 & & & $6.6 \pm 1.1$ & $>120$ & 59 & $>120$ \\
\hline 10 & & & $2.5 \pm 0.7$ & $>120$ & 50 & $>120$ \\
\hline 11 & & & $9.9 \pm 4.5$ & $>120$ & 81 & $>120$ \\
\hline 12 & & & $4.7 \pm 1.5$ & $>120$ & 134 & $>120$ \\
\hline 13 & & & $4.1 \pm 1.7$ & $>120$ & 17 & 13 \\
\hline 14 & & & $2.1 \pm 0.7$ & $>120$ & 0 & 0 \\
\hline 15 & & & $2.2 \pm 0.5$ & $>120$ & 2 & $<5$ \\
\hline 16 & & & $1.3 \pm 0.3$ & $>120$ & 2 & $<5$ \\
\hline 17 & & & $7.0 \pm 2.8$ & $>120$ & 9 & 29 \\
\hline 18 & & & $2.4 \pm 0.4$ & $>120$ & 6 & 23 \\
\hline
\end{tabular}

${ }^{a}$ IC50 values are reported as mean \pm SD values of three determinations.

to the preference that the enzyme has for substrates containing more double bonds. ${ }^{39}$

Potency, Chemical, and Metabolic Stability. The previously reported covalent inhibitors of AC have limited stability. ${ }^{33,34}$ In this respect, we selected our most active compounds 9-18 to further characterize their stability (Table 3). We tested their chemical stability in neutral buffered solution in PBS at $\mathrm{pH} 7.4$ and acetate at $\mathrm{pH} 4.5$, and used mouse plasma to test their metabolic stability. Notably, depending on the heterocycle, the half-life of each compound ranged from a few minutes $(13-18)$ to 1 or $2 \mathrm{~h}(9-12)$ in neutral buffered solution. This difference in stability was even more pronounced in plasma where, remarkably, 9-12 had a half-life of over $2 \mathrm{~h}$.

To further investigate whether additional modifications of the heterocycle core could improve the potency and stability of our best AC inhibitors, we focused on the benzimidazole heterocycle core of 9 and 10, which presented the best compromise between potency and stability (Table 3 ). Since a phenyl group is preferred in the aliphatic tail, we studied a new set of compounds with modifications at the benzimidazole 2 position, while maintaining the 4-phenylbutyl tail linked to the urea (Table 4). The presence of an amino group at postion 2 (8) returned an $\mathrm{IC}_{50}=0.9 \mathrm{nM}$, twice as potent as the nonsubstituted benzimidazole (10). Interestingly, the presence of a methyl group at the same position (22) also produce a compound that was twice as potent as the unsubstituted
Table 4. Additional 2-Benzimidazole Derivative Exploration

\begin{tabular}{|c|c|c|c|c|c|}
\hline \multirow{2}{*}{ Cpd } & \multirow{2}{*}{ Structure } & \multirow{2}{*}{$\begin{array}{c}\mathrm{IC}_{50} \\
(\mathrm{nM})^{\mathrm{a}}\end{array}$} & \multicolumn{3}{|c|}{ Stability $t_{1 / 2}(\min )$} \\
\hline & & & $\begin{array}{l}\text { Buffer } \\
\text { pH 4.5 }\end{array}$ & $\begin{array}{l}\text { Buffer } \\
\text { pH 7.4 }\end{array}$ & $\begin{array}{l}\text { Mouse } \\
\text { plasma }\end{array}$ \\
\hline 8 & & $0.9 \pm 0.2$ & 43 & 14 & 9 \\
\hline 10 & & $2.5 \pm 0.7$ & $>120$ & 50 & $>120$ \\
\hline 19 & & $>10000$ & $>120$ & $>120$ & $>120$ \\
\hline 20 & & $21.0 \pm 6.9$ & $>120$ & $>120$ & $>120$ \\
\hline 21 & & $13.9 \pm 3.9$ & $>120$ & $>120$ & $>120$ \\
\hline 22 & & $1.0 \pm 0.4$ & 8 & 7 & 11 \\
\hline
\end{tabular}

${ }^{a} \mathrm{IC}_{50}$ values are reported as mean \pm SD values of three determinations.

benzimidazole 10. In contrast, introducing a methoxide substituent (21) resulted in a 4-fold decrease in potency, 
Table 5. Exploration of Benzyl Ureas

\begin{tabular}{|c|c|c|c|c|c|c|}
\hline \multirow[b]{2}{*}{ Cpd } & \multirow[b]{2}{*}{$\mathbf{R}$} & \multirow[b]{2}{*}{$\mathbf{X}$} & \multirow{2}{*}{$\begin{array}{c}\mathrm{IC}_{50} \\
(\mathrm{nM})^{\mathrm{a}}\end{array}$} & \multicolumn{3}{|c|}{ Stability $\mathbf{t}_{1 / 2}(\mathrm{~min})$} \\
\hline & & & & $\begin{array}{l}\text { Buffer } \\
\text { pH } 4.5\end{array}$ & $\begin{array}{l}\text { Buffer } \\
\text { pH } 7.4\end{array}$ & $\begin{array}{l}\text { Mouse } \\
\text { plasma }\end{array}$ \\
\hline 8 & & \multirow{5}{*}{$\mathrm{NH}_{2}$} & $0.9 \pm 0.2$ & 43 & 14 & 9 \\
\hline 23 & & & $29.3 \pm 6.2$ & 42 & 13 & 13 \\
\hline 24 & & & $68.4 \pm 3.3$ & 27 & 10 & $<5$ \\
\hline 25 & & & $8.5 \pm 3.3$ & 27 & 11 & $<5$ \\
\hline 26 & & & $7.0 \pm 0.3$ & 34 & 23 & $<5$ \\
\hline 10 & & \multirow{5}{*}{$\mathrm{H}$} & $2.5 \pm 0.7$ & $>120$ & 50 & $>120$ \\
\hline 27 & & & $22.5 \pm 4.6$ & 94 & $>120$ & 108 \\
\hline 28 & & & $55.9 \pm 10.2$ & 82 & 58 & 44 \\
\hline 29 & & & $8.3 \pm 1.5$ & $>120$ & 56 & 71 \\
\hline 30 & & & $14.8 \pm 2.8$ & $>120$ & $>120$ & 94 \\
\hline
\end{tabular}

${ }^{a} \mathrm{IC}_{50}$ values are reported as mean $\pm \mathrm{SD}$ values of three determinations.

with an $\mathrm{IC}_{50}=13.9 \mathrm{nM}$. Finally, we considered the 3dihydrobenzimidazol-2-one heterocycle, which has two nitrogen atoms that can be derivatized. Thus, we obtained 19 with just one urea, which was surprisingly inactive, while 20 with two substituents was almost 10 -fold less potent than the unsubstituted benzimidazole 10. The activity with two substituents as in 20, compared to the inactive derivative 19, is also confirmed by analogues 35 and 36 (see Supporting Information) and remains a puzzling result that merits further investigation. In terms of stability, substituents introduced at the benzimidazole 2-position, as in $\mathbf{8}$ and 22, resulted in less chemically stable compounds ( $t_{1 / 2} 14$ and $7 \mathrm{~min}$, respectively). This suggests that modifications introduced to make the urea group more sensitive to the Cys-143 nucleophilic attack may potentially render these compounds more easily hydrolyzable in solution.

Encouraged by the fact that a phenyl group in the aliphatic tail consistently increased the potency of our inhibitors, we further explored the presence of a benzyl group in this part of the molecule. All of the resulting compounds had a benzyl group directly attached to the urea. We expected this to affect the electrophilic properties of the carbonyl group. For these compounds, we used benzimidazole and 2-aminobenzimidazole cores, which offer the best balance between potency and stability. This generated eight new derivatives (Table 5, 23-26 and 27-30, i.e., four new derivatives per core).

Substituting the 4-phenylbutyl tail for a benzyl tail in the 2aminobenzimidazole and benzimidazole heterocycles produced 23 and 27, which both had diminished potency (35-fold and 7fold decrease, respectively). Moreover, the position of a methyl group in the benzyl tail affected AC activity in different ways. For example, ortho-substitution in $\mathbf{2 4}$ and $\mathbf{2 8}$ resulted in an $\sim 2$ fold decrease in potency compared with that of the nonsubstituted benzyl derivatives $\mathbf{2 3}$ and $\mathbf{2 7}$. This is likely due to the bigger steric hindrance of the ortho-substituted compounds, which occlude the urea electrophilic center. In fact, meta- and para-substitutions, 25,26 and 29,30, have a better inhibitory potency, even compared to that of the benzyl derivatives 23 and 27. Again, this is probably due to an increased lipophilicity of these meta- and para-substituted compounds, compared to that of nonsubstituted benzyl urea. This is in accordance with the hydrophobic nature of the natural AC substrate.

Related to the stability of these benzyl derivatives, a significant effect was again observed depending on the heterocycles. In agreement with 8 containing 4-phenylbutyl urea (Table 5), derivatives based on the 2 -aminobenzimidazole heterocycle were less stable (chemically and metabolically) than those based on the benzimidazole heterocycle, resulting in half- 
A

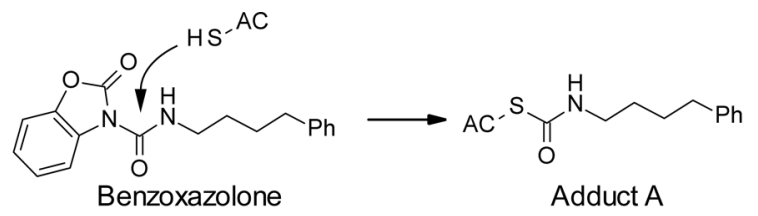<smiles>[R]c1nc2ccccc2n1C(=O)OCCCC</smiles>

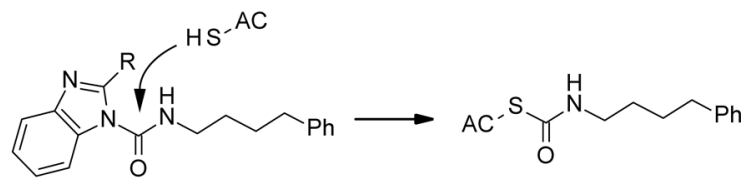

Adduct B

$\mathrm{R}=\mathrm{H}$. Compound 10

Adduct A

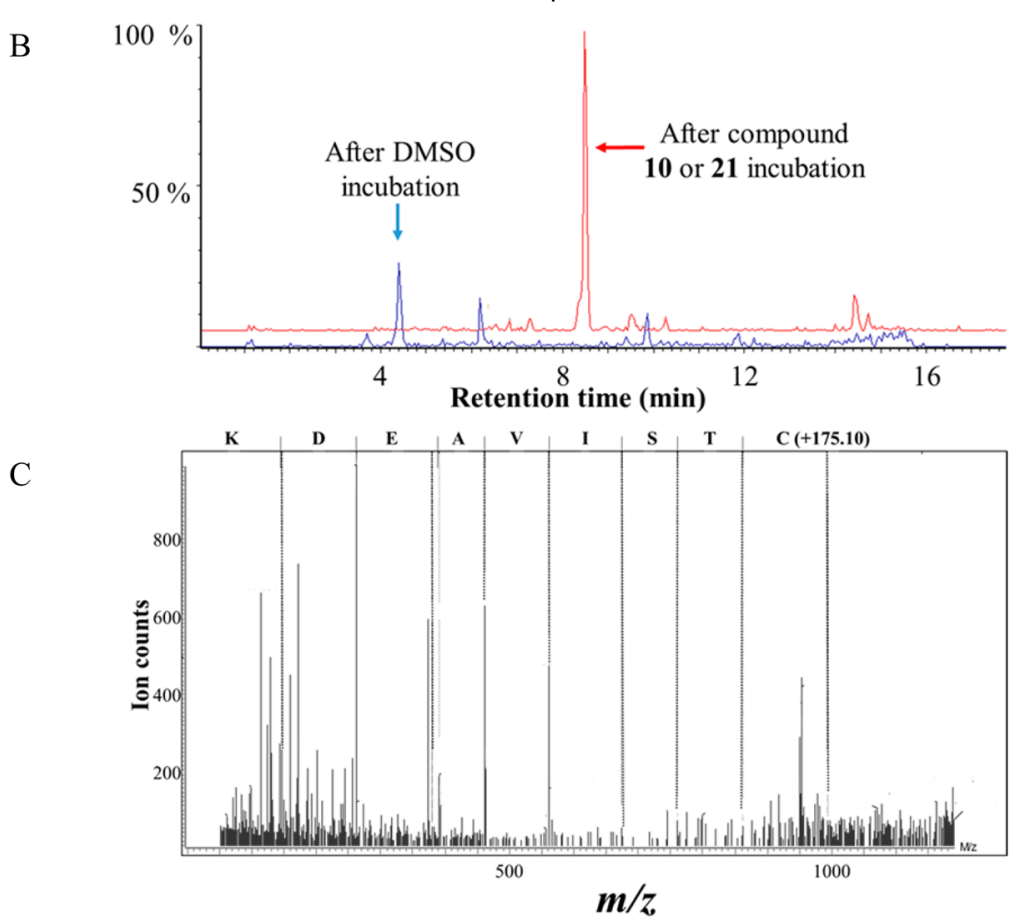

Figure 3. (A) Adduct formed by covalent modification of catalytic Cys-143 by a reported benzoxazolone AC inhibitor ${ }^{33,34}$ and possible adducts formed upon nucleophilic attack of the catalytic Cys-143 on compounds 10 and 21. (B) Chromatograms of peptide analysis after trypsin digestion of AC incubated with compound $\mathbf{1 0}$ or $\mathbf{2 1}$ (red trace) and DMSO (blue trace). (C) Tandem mass spectrum confirming the CTSIVAEDK peptide sequence and mass increased of covalently modified Cys-143 $(+175.10 \mathrm{Da})$, in concordance with adduct A formation $\left(+\mathrm{C}_{11} \mathrm{H}_{13} \mathrm{NO}\right)$. See also Supporting Information.

life values of less than $30 \mathrm{~min}$. However, for benzimidazole derivatives, both benzyl and 4-methylbenzyl substituents returned more stable compounds, reaching $>120 \mathrm{~min}$ as halftime, with potency in the low nanomolar range (see 27 and $\mathbf{3 0}$ in Table 5). These results support this para-substituted benzyl fragment as a valid alternative to our pharmacophore aliphatic tails.

Study of the Mechanism of Inhibition. A covalent mechanism of action has been proved for previously reported benzoxazolone AC inhibitors. ${ }^{33,34}$ Specifically, it was confirmed that Cys-143 attacks the urea carbonyl group of the benzoxazolone, with the 4-phenylbutyl remaining attached to the enzyme AC (Figure 3). As for the benzoxazolone carboxamides, ${ }^{33,34}$ here we used liquid chromatography-mass spectrometry (LC-MS) to characterize the mode of action of compounds 10 and 21. As expected, results demonstrate that these compounds act through the same mechanism of action observed for benzoxazolone AC inhibitors (adduct A, Figure $3 A)$. Incubation with purified recombinant human $A C$, followed by trypsin digestion and peptide analysis by LC-MS, showed the formation of an adduct with the $\mathrm{N}$-terminal peptide of AC (CTSIVAEDK, Figure 3B, red trace) for both inhibitors. In contrast, only native unmodified peptide was observed after control incubation of AC with DMSO. For both compounds $\mathbf{1 0}$ and 21, tandem MS analysis showed the formation of the same adduct (Figure 3C). That is, a peak of the 4-phenylbutyl carboxamide fragment (adduct A) was observed (see Supporting Information). ${ }^{33,34}$ No evidence supporting an alternative mode of action and no adducts with other AC tryptic peptides were observed, which indicate that our new compounds covalently bind to Cys-143.

Computational Analysis. On the most potent and promising AC inhibitors (compounds 8, 10, and 19-22), we performed a coordinate scan analysis as a function of the dihedral angle $\psi$ centered along the $\mathrm{N} 1-\mathrm{Cl}^{\prime}$ axis of the $\mathrm{C} 2-$ $\mathrm{N} 1-\mathrm{Cl}^{\prime}-\mathrm{O} 1^{\prime}$ atoms of the urea moiety. ${ }^{40,41}$ In this way, we could identify the most probable (i.e., lowest energy) conformations, which are likely adopted by urea during nucleophilic attack by the Cys-143 residue in AC, generating the covalent enzyme-ligand adduct. ${ }^{42-45}$ 

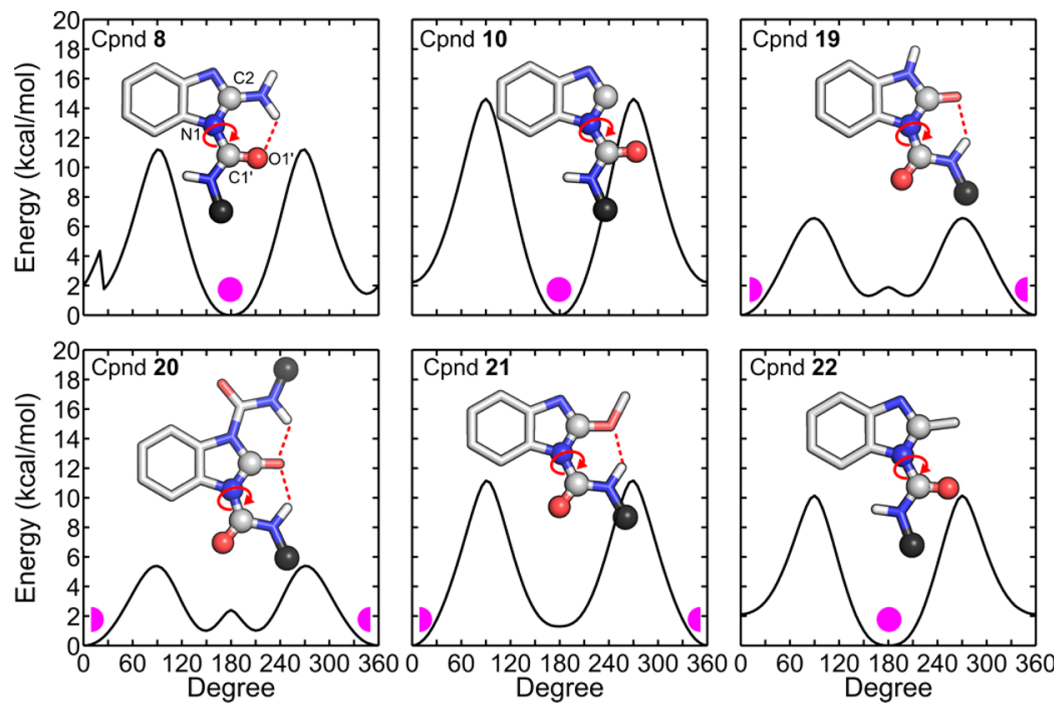

Figure 4. Coordinate scan of the urea torsional angles of compounds 8, 10, and 19-22. The pink sphere represents the global minimum conformation, which is shown as a $2 \mathrm{D}$ structure. The exo conformation is preferred for 8, 10, and 22 and the endo conformation for 19-21. The dark gray spheres in position 1 represent the phenylbutyl moiety.

Table 6. Effect of AC Inhibitors in Melanoma Cells

\begin{tabular}{|c|c|c|c|c|}
\hline Compound & Structure & $\begin{array}{c}\text { IC }_{50}(\mathrm{nM}) \\
\text { Enzyme }^{\mathrm{a}}\end{array}$ & $\begin{array}{l}\mathrm{IC}_{50}(\mathrm{nM}) \\
\mathrm{A375} \text { cells }^{\mathrm{a}}\end{array}$ & $\begin{array}{c}\mathrm{IC}_{50}(\mathrm{nM}) \\
\mathrm{G}-361 \text { cells }^{\mathrm{a}}\end{array}$ \\
\hline Carmofur & & $20.7 \pm 4.1$ & $190.8 \pm 2.5$ & $758.5 \pm 434.9$ \\
\hline 10 & & $2.5 \pm 0.7$ & $75.6 \pm 3.3$ & $229.7 \pm 69.6$ \\
\hline 21 & & $13.9 \pm 3.9$ & $966.9 \pm 80.9$ & $2784.1 \pm 781.6$ \\
\hline 27 & & $22.5 \pm 4.6$ & $1061.5 \pm 72.8$ & $2799.0 \pm 883.9$ \\
\hline 30 & & $14.8 \pm 2.8$ & $505.3 \pm 29.6$ & $928.3 \pm 54.8$ \\
\hline
\end{tabular}

${ }^{a} \mathrm{IC}_{50}$ values are reported as mean $\pm \mathrm{SD}$ values of at least two determinations

As expected, in all of the compounds we detected two energetic minima for $\psi$. One was located at $\psi=180^{\circ}$, where the oxygen atom of the urea group at position 1 is oriented toward the "outer" side of the molecule (hereafter referred to as the exo conformation, Figure 4). One was located at $\psi=360^{\circ}$, where the oxygen atom points toward the "inner" side of the molecule (hereafter referred to as the endo conformation, Figure 4). Interestingly, the most active compounds 8, 10, and $22\left(\mathrm{IC}_{50}\right.$ of $0.9 \pm 0.2 \mathrm{nM}, 2.5 \pm 0.1 \mathrm{nM}$, and $1.0 \pm 0.4 \mathrm{nM}$, respectively) prefer the exo conformation, while the others prefer endo conformations. Compound $\mathbf{8}$ is highly stabilized in exo thanks to the formation of an intramolecular $\mathrm{H}$-bond between the amino group in position 2 and the oxygen atom of the urea. However, exo conformations are also preferred in $\mathbf{1 0}$ and 22 in the absence of this H-bond, indicating that this conformation is stabilized by the nature of the central core. In fact, the less active compounds 19-21, $\left(\mathrm{IC}_{50}\right.$ of $>10000 \mathrm{nM}$, $21.0 \pm 6.9 \mathrm{nM}$, and $13.9 \pm 3.9 \mathrm{nM}$, respectively) prefer the endo conformation in which they form an intramolecular $\mathrm{H}$ bond (Figure 4). These results suggest that the nucleophilic attack performed by Cys-143 is favored when urea assumes the exo conformation, which therefore identifies more potent compounds. In other words, based on our computational analysis, we hypothesize that the $\mathrm{AC}$ active site is more selective toward the exo conformation of the amide group of the inhibitor. Then, when bound, the amide bond might undergo a slight distortion, which has been suggested to facilitate the nucleophilic attack for amide hydrolysis. 46,47 
In conclusion, the minimal energy conformation assumed by $\psi$ and, in particular, the stabilization of the exo conformation seems to be an important prerequisite for the rational design of a potent compound against $\mathrm{AC}^{48}$

Targeting AC in Melanoma Cells. On the basis of in vitro activity results on AC inhibition, as well as on the stability studies, benzimidazole derivatives 10, 21, 27, and 30 were also tested for their ability to inhibit endogenous AC in intact cells. The assay is based on the intracellular enzymo-chemical transformation of the AC substrate Rbm-14-12 into fluorescent umbelliferone. ${ }^{50}$ To this end, we used two different melanoma cell lines, A375 and G-361, which are representative of the invasive and proliferative phenotype of the disease, respectively. ${ }^{49}$ After $2 \mathrm{~h}$ of treatment, all four compounds inhibited endogenous AC activity with variable potencies in both cell lines (Table 6). The A375 cell line was more sensitive to AC inhibition than G-361. This difference is likely due to the higher levels of expression of catalytically competent AC in proliferative G-361 melanoma cells than in invasive A375 cells. ${ }^{49}$ The inhibitory activity of these compounds against AC in intact cells correlated well with that obtained in vitro, with 10 being the most potent and promising compound. In addition, the benzimidazole derivatives had improved stability and comparable potency to carmofur, which has been used to generate similarly active derivatives to block AC. ${ }^{49}$ The effect observed for these compounds in melanoma cells can be attributed to their ability to block AC activity. In fact, under these experimental conditions, we did not observe any cytotoxic effect of the compounds, alone. Moreover, cytotoxicity assays treating the cells for $72 \mathrm{~h}$ demonstrated the lack of cytotoxicity (see Supporting Information).

\section{CONCLUSIONS}

In the present work, we have identified a pharmacophore model that captures essential features for covalent inhibition of the AC enzyme. Our results show that a chemical structure formed by a $6+5$ fused ring heterocycles, functionalized at the endocyclic amino group, is critical for AC inhibition. Although all of the fused ring heterocycles considered were quite potent, each returned different results in terms of chemical stability. In this regard, benzimidazole derivatives showed the best balance between potency and stability. Exploration of 2-benzimidazole substituents yielded slightly more potent compounds when an electrodonating group was inserted, as in $\mathbf{8}$ and $\mathbf{2 2}$. However, electron withdrawing substituents helped both chemical and metabolic stabilities, with a compound half-life of more than 2 h. Our findings also show that compounds with an aliphatic chain that contains an aromatic group are more potent in blocking AC. We have demonstrated this for tails based on a 4phenylbutyl fragment as in $10,12,14,16$, and 18, compared to those with the hexyl group as in $9,11,13,15$, and 17. Along these lines, a benzyl fragment in the tail showed different effects depending on methyl substituent position. While a naked benzyl fragment resulted in less potent compounds, as in $\mathbf{2 3}$ and 27, the presence of a methyl group showed different effects depending on its position. Ortho-substitution, as in 24 and 28, had diminished potency, probably due to a larger steric hindrance. We also observed a slight decrease in potency for meta-derivatives, as in $\mathbf{2 5}$ and $\mathbf{2 9}$, and para-derivatives, as in $\mathbf{2 6}$ and 30, especially for benzimidazole heterocycle. Benzyl substituents also affected chemical and metabolic stabilities. For example, 2-aminobenzimidazole derivatives are unstable compounds. However, when the benzimidazole core is linked to either a benzyl or a para-methylbenzyl group, compounds become more stable, reaching an optimal half-time that exceeds $2 \mathrm{~h}$, as for $\mathbf{2 7}$ and $\mathbf{3 0 .}$

In summary, our scaffold exploration and derivatization suggest a general pharmacophore for AC inhibition formed by a $6+5$ fused ring heterocycle bearing a urea at an endocyclic nitrogen group. This nitrogen should be derivatized with an alkyl chain presenting a phenyl substituent. In our study, this general scaffold resulted in benzimidazole derivatives 10, 21, 27, and 30, which are potent and fairly stable AC inhibitors, with promising activity against $\mathrm{AC}$ in different melanoma cell lines. These novel AC inhibitors merit further characterization and can serve as a promising starting point for the discovery of new therapeutics for melanoma.

\section{EXPERIMENTAL SECTION}

Chemistry. All of the commercially available reagents and solvents were used as purchased from vendors without further purification. Dry solvent pyridine was purchased from Sigma-Aldrich. Automated column chromatography purifications were done using a Teledyne ISCO apparatus (CombiFlash $R_{\mathrm{f}}$ ) with prepacked silica gel columns of different sizes (from $4 \mathrm{~g}$ up to $24 \mathrm{~g}$ ) and mixtures of increasing polarity of cyclohexane and ethyl acetate (EtOAc) or cyclohexane and tertbutyl methyl ether (TBME). NMR experiments were run on a Bruker Avance III 400 system (400.13 MHz for ${ }^{1} \mathrm{H}$ and $100.62 \mathrm{MHz}$ for ${ }^{13} \mathrm{C}$ ), equipped with a BBI probe and Z-gradients. Spectra were acquired at $300 \mathrm{~K}$, using deuterated dimethyl sulfoxide (DMSO- $d_{6}$ ) or deuterated chloroform $\left(\mathrm{CDCl}_{3}\right)$ as solvents. UPLC/MS analyses were run on a Waters Acquity UPLC/MS system consisting of an SQD (single quadrupole detector) mass spectrometer equipped with an electrospray ionization interface and a photodiode array detector. The PDA range was $210-400 \mathrm{~nm}$. Analyses were performed on an Acquity UPLC BEH C ${ }_{18}$ column $(100 \times 2.1 \mathrm{~mm} \mathrm{ID}$, particle size $1.7 \mu \mathrm{m})$ with a VanGuard $\mathrm{BEH} \mathrm{C}_{18}$ precolumn $(5 \times 2.1 \mathrm{~mm}$ ID, particle size 1.7 $\mu \mathrm{m})$. Mobile phase was $10 \mathrm{mM} \mathrm{NH} \mathrm{N}_{4} \mathrm{OAc}$ in $\mathrm{H}_{2} \mathrm{O}$ at pH 5 adjusted with $\mathrm{CH}_{3} \mathrm{COOH}(\mathrm{A})$ and $10 \mathrm{mM} \mathrm{NH} \mathrm{NHAc}_{4} \mathrm{On} \mathrm{CH}_{3} \mathrm{CN}-\mathrm{H}_{2} \mathrm{O}$ (95:5) at $\mathrm{pH} 5.0$ (B). Depending on the analysis method used, a different gradient increasing the proportion of mobile phase $\mathrm{B}$ was applied. For analysis method 1, the mobile-phase B proportion increased from 5\% to $95 \%$ in $3 \mathrm{~min}$. For analysis method 2, the mobile-phase B proportion increased from $50 \%$ to $100 \%$ in $3 \mathrm{~min}$. Electrospray ionization in positive and negative modes was applied. All tested compounds showed $\geq 95 \%$ purity by NMR and UPLC/MS analysis.

General Procedure for Urea Synthesis. Under $\mathrm{N}_{2}$ atmosphere, to a room temperature solution of corresponding heterocycle (1.0 $\mathrm{mmol})$ and 4-(Dimethylamino)pyridine $(0.1 \mathrm{mmol})$ in dry pyridine $(2.7 \mathrm{~mL})$ was dropwise added corresponding isocyanate $(1.0 \mathrm{mmol})$. Then, the reaction crude was stirred at room temperature for $5 \mathrm{~h}$, portioned between EtOAc $(20 \mathrm{~mL})$ and $\mathrm{NaHCO}_{3}$ saturated solution $(20 \mathrm{~mL})$, and the organic layer extracted with brine $(20 \mathrm{~mL})$, dried over $\mathrm{Na}_{2} \mathrm{SO}_{4}$, and concentrated to dryness at low pressure. The pure compounds were afforded by purification by typical silica gel flash chromatography, using mixtures of increasing polarity of cyclohexane and EtOAc or tert-butyl methyl ether (TBME), followed by trituration in diethyl ether.

Synthesis of 1-(1,3-Benzothiazol-2-yl)-3-hexyl-urea (1) in Table 1. Compound 1 was synthesized following the general procedure previously described using 2-aminobenzothiazole (100 mg, 0.65 mmol) and hexyl isocyanate $(0.10 \mathrm{~mL}, 0.65 \mathrm{mmol})$. Purification by typical silica gel flash chromatography (cyclohexane/TBME from 95:5 to $70: 30)$ and final trituration in diethyl ether twice $(2 \times 1 \mathrm{~mL})$ afforded $1(111 \mathrm{mg}, 64 \%)$ as a white solid. $\mathrm{Rt}=2.70 \mathrm{~min}$ (analysis method 1). MS (ESI) $m / z: 278.1[\mathrm{M}-\mathrm{H}]^{+}$, calculated 278.1. ${ }^{1} \mathrm{H}$ NMR $\left(400 \mathrm{MHz}\right.$, DMSO- $\left.d_{6}\right) \delta 10.58(\mathrm{~s}, 1 \mathrm{H}), 7.85(\mathrm{~d}, J=7.1 \mathrm{~Hz}$, $1 \mathrm{H}), 7.59(\mathrm{~d}, J=7.9 \mathrm{~Hz}, 1 \mathrm{H}), 7.40-7.27(\mathrm{~m}, 1 \mathrm{H}), 7.19(\mathrm{~m}, 1 \mathrm{H}), 6.74$ $(\mathrm{t}, J=5.6 \mathrm{~Hz}, 1 \mathrm{H}), 3.12-3.16(\mathrm{~m}, 2 \mathrm{H}), 1.44(\mathrm{q}, J=7.0 \mathrm{~Hz}, 2 \mathrm{H})$, $1.35-1.23(\mathrm{~m}, 6 \mathrm{H}), 0.92-0.79(\mathrm{~m}, 3 \mathrm{H}) .{ }^{13} \mathrm{C}$ NMR (101 MHz, DMSO- $\left.d_{6}\right) \delta 125.71(\mathrm{CH}), 122.54(\mathrm{CH}), 121.28(\mathrm{CH}), 119.82(\mathrm{CH})$, 
$39.08\left(\mathrm{CH}_{2}\right), 30.93\left(\mathrm{CH}_{2}\right), 29.36\left(\mathrm{CH}_{2}\right), 25.96\left(\mathrm{CH}_{2}\right), 22.06\left(\mathrm{CH}_{2}\right)$, $13.91\left(\mathrm{CH}_{3}\right)$. qNMR: $97.3 \%$.

Synthesis of 1-(1,3-Benzothiazol-2-yl)-3-(4-phenylbutyl)urea (2). Compound 2 was synthesized following the general procedure previously described using 2-aminobenzothiazole $(50 \mathrm{mg}, 0.32$ mmol) and 4-phenylbutyl isocyanate $(0.06 \mathrm{~mL}, 0.32 \mathrm{mmol})$. Purification by typical silica gel flash chromatography (cyclohexane/ TBME from 95:5 to 60:40) and final trituration in diethyl ether twice $(2 \times 1 \mathrm{~mL})$ afforded $2(89 \mathrm{mg}, 85 \%)$ as a white solid. $\mathrm{Rt}=2.73 \mathrm{~min}$ (analysis method 1). MS (ESI) $m / z: 326.1[\mathrm{M}-\mathrm{H}]^{+}$, calculated 326.1. ${ }^{1} \mathrm{H}$ NMR (400 MHz, DMSO- $\left.d_{6}\right) \delta 10.59(\mathrm{~s}, 1 \mathrm{H}), 7.86(\mathrm{~d}, J=$ $7.8 \mathrm{~Hz}, 1 \mathrm{H}), 7.60(\mathrm{~d}, J=8.0 \mathrm{~Hz}, 1 \mathrm{H}), 7.35(\mathrm{td}, J=7.7,1.2 \mathrm{~Hz}, 1 \mathrm{H})$, $7.27(\mathrm{t}, J=7.5 \mathrm{~Hz}, 2 \mathrm{H}), 7.23-7.19(\mathrm{~m}, 3 \mathrm{H}), 7.21-7.12(\mathrm{~m}, 1 \mathrm{H}), 6.77$ $(\mathrm{t}, 1 \mathrm{H}), 3.19(\mathrm{q}, J=6.6 \mathrm{~Hz}, 2 \mathrm{H}), 2.60(\mathrm{t}, J=7.5 \mathrm{~Hz}, 2 \mathrm{H}), 1.68-1.54$ $(\mathrm{m}, 2 \mathrm{H}), 1.54-1.41(\mathrm{~m}, 2 \mathrm{H}) .{ }^{13} \mathrm{C}$ NMR (101 MHz, DMSO-d 6 ) $\delta$ $142.09(\mathrm{CH}), 128.29(\mathrm{CH}), 128.24(\mathrm{CH}), 125.72(\mathrm{CH}), 125.67$ $(\mathrm{CH}), 122.56(\mathrm{CH}), 121.29(\mathrm{CH}), 38.98\left(\mathrm{CH}_{2}\right), 34.76\left(\mathrm{CH}_{2}\right), 29.09$ $\left(\mathrm{CH}_{2}\right), 28.33\left(\mathrm{CH}_{2}\right)$. qNMR: $97.5 \%$.

Synthesis of 1-(1,3-Benzoxazol-2-yl)-3-hexyl-urea (3). Compound 3 was synthesized following the general procedure previously described using 2-aminobenzoxazole (100 $\mathrm{mg}, 0.72 \mathrm{mmol}$ ) and hexyl isocyanate $(0.11 \mathrm{~mL}, 0.72 \mathrm{mmol})$. Purification by typical silica gel flash chromatography (cyclohexane/TBME from 95:5 to 70:30) and final trituration in diethyl ether twice $(2 \times 1 \mathrm{~mL})$ afforded $3(48$ $\mathrm{mg}, 64 \%)$ as a white solid. Rt $=2.81 \mathrm{~min}$ (analysis method 1). MS (ESI) $m / z: 262.1[\mathrm{M}-\mathrm{H}]^{+}$, calculated 262.2. ${ }^{1} \mathrm{H}$ NMR (400 MHz, DMSO- $\left.d_{6}\right) \delta 11.03(\mathrm{~s}, 1 \mathrm{H}), 8.39(\mathrm{t}, J=5.7 \mathrm{~Hz}, 1 \mathrm{H}), 7.55(\mathrm{~d}, J=7.5$ $\mathrm{Hz}, 1 \mathrm{H}), 7.50(\mathrm{~d}, J=7.5 \mathrm{~Hz}, 1 \mathrm{H}), 7.28(\mathrm{td}, J=7.7,1.2 \mathrm{~Hz}, 1 \mathrm{H}), 7.21$ $(\mathrm{td}, J=7.7,1.2 \mathrm{~Hz}, 1 \mathrm{H}), 3.30-3.20(\mathrm{~m}, 2 \mathrm{H}), 1.52(\mathrm{q}, J=7.3 \mathrm{~Hz}, 2 \mathrm{H})$, $1.37(\mathrm{~m}, 6 \mathrm{H}), 0.98-0.77(\mathrm{~m}, 3 \mathrm{H}) .{ }^{13} \mathrm{C} \mathrm{NMR}\left(101 \mathrm{MHz}, \mathrm{DMSO}-d_{6}\right) \delta$ 157.18 (CO), 151.95 (C), 146.95 (C), $140.31(\mathrm{C}), 124.53(\mathrm{CH})$, $122.89(\mathrm{CH}), 117.14(\mathrm{CH}), 109.77(\mathrm{CH}), 39.37\left(\mathrm{CH}_{2}\right), 30.89\left(\mathrm{CH}_{2}\right)$, $29.29\left(\mathrm{CH}_{2}\right), 25.98\left(\mathrm{CH}_{2}\right), 22.04\left(\mathrm{CH}_{2}\right), 13.88\left(\mathrm{CH}_{3}\right)$. qNMR: $97.1 \%$.

Synthesis of 1-(1,3-Benzoxazol-2-yl)-3-(4-phenylbutyl)urea (4). Compound 4 was synthesized following the general procedure previously described using 2-aminobenzoxazole $(50 \mathrm{mg}, 0.36 \mathrm{mmol})$ and 4-phenylbutyl isocyanate $(0.06 \mathrm{~mL}, 0.36 \mathrm{mmol})$. Purification by typical silica gel flash chromatography (cyclohexane/TBME from 100:0 to $80: 20)$ and final trituration in diethyl ether twice $(2 \times 1 \mathrm{~mL})$ afforded $4(65 \mathrm{mg}, 57 \%)$ as a white solid. Rt $=2.80 \mathrm{~min}$ (analysis method 1). MS (ESI) $m / z: 310.1[\mathrm{M}-\mathrm{H}]^{+}$, calculated 310.2. ${ }^{1} \mathrm{H}$ NMR $\left(400 \mathrm{MHz}\right.$, DMSO- $\left.d_{6}\right) \delta 11.03(\mathrm{~s}, 1 \mathrm{H}), 8.39(\mathrm{t}, J=5.7 \mathrm{~Hz}, 1 \mathrm{H})$, $7.55(\mathrm{~d}, J=7.7 \mathrm{~Hz}, 1 \mathrm{H}), 7.49(\mathrm{~d}, J=7.7 \mathrm{~Hz}, 1 \mathrm{H}), 7.32-7.23(\mathrm{~m}, 3 \mathrm{H})$, $7.23-7.11(\mathrm{~m}, 4 \mathrm{H}), 3.28(\mathrm{q}, J=6.6 \mathrm{~Hz}, 2 \mathrm{H}), 2.62(\mathrm{t}, J=7.5 \mathrm{~Hz}, 2 \mathrm{H})$, $1.67-1.61(\mathrm{~m}, 2 \mathrm{H}), 1.59-1.49(\mathrm{~m}, 2 \mathrm{H}) .{ }^{13} \mathrm{C}$ NMR $(101 \mathrm{MHz}$, DMSO-d $\left.d_{6}\right) \delta 157.17$ (CO), 151.99 (C), 146.97 (C), 142.09 (C), $140.31(\mathrm{C}), 128.29(\mathrm{CH}), 128.24(\mathrm{CH}), 125.67(\mathrm{CH}), 124.54(\mathrm{CH})$, $122.91(\mathrm{CH}), 117.15(\mathrm{CH}), 109.78(\mathrm{CH}), 38.76\left(\mathrm{CH}_{2}\right), 34.73\left(\mathrm{CH}_{2}\right)$, $29.02\left(\mathrm{CH}_{2}\right), 28.34\left(\mathrm{CH}_{2}\right)$. qNMR: $97.4 \%$.

Synthesis of 1-(1H-Benzimidazol-2-yl)-3-hexyl-urea (5). Step 1. Synthesis of tert-Butyl 2-aminobenzimidazole-1-carboxylate (31). A room temperature solution of 2-aminobenzimidazole $(200.0 \mathrm{mg}, 1.46$ $\mathrm{mmol})$, di-tert-butyl dicarbonate $(327.8 \mathrm{mg}, 1.46 \mathrm{mmol})$, and triethylamine $(0.6 \mathrm{~mL}, 4.37 \mathrm{mmol})$ in dry THF $(2.4 \mathrm{~mL})$ was stirred at room temperature for $5 \mathrm{~h}$. Then, the reaction crude was portioned between AcOEt $(20 \mathrm{~mL})$ and $\mathrm{NaHCO}_{3}$ saturated solution $(20 \mathrm{~mL})$, and the organic layer extracted with brine $(20 \mathrm{~mL})$, dried over $\mathrm{Na}_{2} \mathrm{SO}_{4}$, and concentrated to dryness at low pressure. Purification by typical silica gel flash chromatography (cyclohexane/AcOEt from $75: 25$ to $65: 45)$ afforded 31 (323 mg, 95\%) as a white solid. Rt $=2.03$ min (analysis method 1). MS (ESI) $m / z: 234.2[\mathrm{M}-\mathrm{H}]^{+}$, calculated 234.1. ${ }^{1} \mathrm{H}$ NMR (400 MHz, $\left.\mathrm{CDCl}_{3}\right) \delta 7.61(\mathrm{~d}, J=8.0 \mathrm{~Hz}, 1 \mathrm{H}), 7.34$ $(\mathrm{d}, J=7.5 \mathrm{~Hz}, 1 \mathrm{H}), 7.20(\mathrm{td}, J=7.5,1.2 \mathrm{~Hz}, 1 \mathrm{H}), 7.06(\mathrm{td}, J=8.0,1.2$ $\mathrm{Hz}, 1 \mathrm{H}), 6.20(\mathrm{~s}, 2 \mathrm{H}), 1.72(\mathrm{~s}, 9 \mathrm{H})$.

Step 2. tert-Butyl 2-(hexylcarbamoylamino)benzimidazole-1carboxylate (32). To a room temperature solution of 31 (160 mg, $0.68 \mathrm{mmol})$ and 4 -(dimethylamino)pyridine $(8.4 \mathrm{mg}, 0.07 \mathrm{mmol})$ in dry pyridine $(1.8 \mathrm{~mL})$ was dropwise added hexyl isocyanate $(0.10 \mathrm{~mL}$, $0.68 \mathrm{mmol})$. Then, the reaction crude was stirred at $80{ }^{\circ} \mathrm{C}$ for $3 \mathrm{~h}$, portioned between AcOEt $(20 \mathrm{~mL})$ and $\mathrm{NaHCO}_{3}$ saturated solution
$(20 \mathrm{~mL})$, and the organic layer extracted with brine $(20 \mathrm{~mL})$, dried over $\mathrm{Na}_{2} \mathrm{SO}_{4}$, and concentrated to dryness at low pressure. Purification by typical silica gel flash chromatography (cyclohexane/AcOEt from 100:0 to $75: 25)$ afforded $32(27 \mathrm{mg}, 11 \%)$ as a white solid. $\mathrm{Rt}=2.45$ min (analysis method 2). MS (ESI) $m / z: 361.2[\mathrm{M}-\mathrm{H}]^{+}$, calculated 361.2. ${ }^{1} \mathrm{H}$ NMR (400 MHz, DMSO- $\left.d_{6}\right) \delta 11.44(\mathrm{~s}, 1 \mathrm{H}), 9.75(\mathrm{~s}, 1 \mathrm{H})$, $7.44-7.25(\mathrm{~m}, 2 \mathrm{H}), 7.04-6.97(\mathrm{~m}, 2 \mathrm{H}), 3.18(\mathrm{td}, J=6.9,5.7 \mathrm{~Hz}, 2 \mathrm{H})$, $1.56-1.38(\mathrm{~m}, 2 \mathrm{H}), 1.52(\mathrm{~s}, 9 \mathrm{H}), 1.37-1.22(\mathrm{~m}, 6 \mathrm{H}), 0.98-0.77(\mathrm{~m}$, $3 \mathrm{H})$.

Step 3. Synthesis of 1-(1H-Benzimidazol-2-yl)-3-hexyl-urea (5). A solution of $32(26 \mathrm{mg}, 0.07 \mathrm{mmol})$ in dry pyridine $(0.2 \mathrm{~mL})$ was stirred at $80{ }^{\circ} \mathrm{C}$ for $16 \mathrm{~h}$, then the reaction crude was concentrated to dryness at low pressure and purified by typical silica gel flash chromatography (cyclohexane/AcOEt from 80:20 to 50:50) and final trituration in diethyl ether twice $(2 \times 1 \mathrm{~mL})$ affording $5(13 \mathrm{mg}, 70 \%)$ as a white solid. Rt $=0.95 \min ($ analysis method 2$)$. MS (ESI) $\mathrm{m} / z$ : $261.2[\mathrm{M}-\mathrm{H}]^{+}$, calculated 261.2. ${ }^{1} \mathrm{H}$ NMR $\left(400 \mathrm{MHz}, \mathrm{DMSO}-d_{6}\right) \delta$ $11.40(\mathrm{~s}, 1 \mathrm{H}), 9.73(\mathrm{~s}, 1 \mathrm{H}), 7.34(\mathrm{dd}, J=7.1,3.5 \mathrm{~Hz}, 2 \mathrm{H}), 7.01(\mathrm{dd}, J$ $=7.1,3.5 \mathrm{~Hz}, 2 \mathrm{H}), 3.26-3.07(\mathrm{~m}, 2 \mathrm{H}), 1.48(\mathrm{dt}, J=14.5,7.2 \mathrm{~Hz}, 2 \mathrm{H})$, 1.37-1.18 (m, 6H), 0.98-0.75 (m, 3H). ${ }^{13} \mathrm{C}$ NMR (101 MHz, DMSO- $\left.d_{6}\right) \delta 154.27(\mathrm{CO}), 148.40(\mathrm{C}), 120.54(\mathrm{CH}), 38.70\left(\mathrm{CH}_{2}\right)$, $30.97\left(\mathrm{CH}_{2}\right), 29.51\left(\mathrm{CH}_{2}\right), 26.03\left(\mathrm{CH}_{2}\right), 22.10\left(\mathrm{CH}_{2}\right), 13.93\left(\mathrm{CH}_{3}\right)$. qNMR: $96.3 \%$.

Synthesis of 1-(1H-Benzimidazol-2-yl)-3-(4-phenylbutyl)urea (6). Step 1. tert-Butyl 2-(4-phenylbutylcarbamoylamino)benzimidazole1-carboxylate (33). To a room temperature solution of $31(160 \mathrm{mg}$, $0.68 \mathrm{mmol})$ and 4 -(dimethylamino)pyridine $(8.4 \mathrm{mg}, 0.07 \mathrm{mmol})$ in dry pyridine $(1.8 \mathrm{~mL})$ was dropwise added 4-phenylbutil isocyanate $(0.12 \mathrm{~mL}, 0.68 \mathrm{mmol})$. Then, the reaction crude was stirred at $80{ }^{\circ} \mathrm{C}$ for $3 \mathrm{~h}$, portioned between AcOEt $(20 \mathrm{~mL})$ and $\mathrm{NaHCO}_{3}$ saturated solution $(20 \mathrm{~mL})$, and the organic layer extracted with brine $(20 \mathrm{~mL})$, dried over $\mathrm{Na}_{2} \mathrm{SO}_{4}$, and concentrated to dryness at low pressure. Purification by typical silica gel flash chromatography (cyclohexane/ TBME from 95:5 to 10:90) afforded $33(34 \mathrm{mg}, 12 \%)$ as a white solid. $\mathrm{Rt}=2.36 \mathrm{~min}$ (analysis method 2). MS (ESI) $\mathrm{m} / z: 409.1[\mathrm{M}-\mathrm{H}]^{+}$, calculated 409.2. ${ }^{1} \mathrm{H}$ NMR $\left(400 \mathrm{MHz}, \mathrm{CDCl}_{3}\right) \delta 9.50(\mathrm{~s}, 1 \mathrm{H}), 9.20(\mathrm{t}$, $J=5.5 \mathrm{~Hz}, 1 \mathrm{H}), 7.70(\mathrm{~d}, J=8.4 \mathrm{~Hz}, 1 \mathrm{H}), 7.46(\mathrm{~d}, J=7.8 \mathrm{~Hz}, 1 \mathrm{H})$, 7.37-7.23 (m, 4H), 7.24-7.07 (m, 3H), 3.58-3.30 (m, 2H), $2.69(\mathrm{t}, J$ $=7.3 \mathrm{~Hz}, 2 \mathrm{H}), 1.89-1.64(\mathrm{~m}, 2 \mathrm{H}), 1.73(\mathrm{~s}, 9 \mathrm{H}), 1.26(\mathrm{t}, J=7.1 \mathrm{~Hz}$, $2 \mathrm{H})$.

Step 2. 1-(1H-Benzimidazol-2-yl)-3-(4-phenylbutyl)urea (6). A solution of $33(34 \mathrm{mg}, 0.08 \mathrm{mmol})$ in dry pyridine $(0.2 \mathrm{~mL})$ was stirred at $80{ }^{\circ} \mathrm{C}$ for $16 \mathrm{~h}$, then the reaction crude was concentrated to dryness at low pressure and purified by typical silica gel flash chromatography (cyclohexane/AcOEt from 80:20 to 50:50), and final trituration in diethyl ether twice $(2 \times 1 \mathrm{~mL})$ afforded $6(18 \mathrm{mg}, 70 \%)$ as a white solid. Rt $=0.95 \mathrm{~min}$ (analysis method 2). MS (ESI) $\mathrm{m} / \mathrm{z}$ : 309.2 $[\mathrm{M}-\mathrm{H}]^{+}$, calculated 309.2. ${ }^{1} \mathrm{H}$ NMR (400 MHz, DMSO- $\left.d_{6}\right) \delta$ $11.42(\mathrm{~s}, 1 \mathrm{H}), 7.40(\mathrm{~s}, 1 \mathrm{H}), 7.34(\mathrm{~m}, 2 \mathrm{H}), 7.27(\mathrm{~m}, 2 \mathrm{H}), 7.23-7.12$ $(\mathrm{m}, 4 \mathrm{H}), 7.01(\mathrm{~m}, 2 \mathrm{H}), 3.22(\mathrm{q}, J=6.5 \mathrm{~Hz}, 2 \mathrm{H}), 2.61(\mathrm{t}, J=7.5 \mathrm{~Hz}$, $2 \mathrm{H}), 1.74-1.56(\mathrm{~m}, 2 \mathrm{H}), 1.56-1.42(\mathrm{~m}, 2 \mathrm{H}) .{ }^{13} \mathrm{C}$ NMR $(101 \mathrm{MHz}$, DMSO- $\left.d_{6}\right) \delta 154.29(\mathrm{CO}), 148.40(\mathrm{C}), 142.13(\mathrm{C}), 128.31(\mathrm{CH})$, 128.27 (CH), $125.69(\mathrm{CH}), 120.53(\mathrm{CH}), 99.54(\mathrm{CH}), 38.60\left(\mathrm{CH}_{2}\right)$, $34.81\left(\mathrm{CH}_{2}\right), 29.23\left(\mathrm{CH}_{2}\right), 28.40\left(\mathrm{CH}_{2}\right)$. qNMR: $96.1 \%$.

Synthesis of 2-Amino-N-hexyl-benzimidazole-1-carboxamide (7). Compound 7 was synthesized following the general procedure previously described using 2-aminobenzimidazole $(211.5 \mathrm{mg}, 1.54$ $\mathrm{mmol})$ and hexyl isocyanate $(0.114 \mathrm{~mL}, 0.68 \mathrm{mmol})$. Purification by typical silica gel flash chromatography (cyclohexane/TBME from 50:50 to 20:80) followed by trituration in $\mathrm{Et}_{2} \mathrm{O}(5 \mathrm{~mL})$ afforded 7 (128 $\mathrm{mg}, 64 \%)$ as a white solid. $\mathrm{Rt}=2.17 \mathrm{~min}$ (analysis method 1$)$. MS (ESI) $m / z: 261.2[\mathrm{M}-\mathrm{H}]^{+}$, calculated 261.2. ${ }^{1} \mathrm{H}$ NMR (400 $\left.\mathrm{MHz}^{\mathrm{CDCl}}{ }_{3}\right) \delta 7.40(\mathrm{~d}, J=7.8 \mathrm{~Hz}, 1 \mathrm{H}), 7.29(\mathrm{~d}, J=7.8 \mathrm{~Hz}, 2 \mathrm{H})$, $7.22(\mathrm{td}, J=7.8,1.2 \mathrm{~Hz}, 2 \mathrm{H}), 7.09(\mathrm{td}, J=7.8,1.2 \mathrm{~Hz}, 2 \mathrm{H}), 3.48(\mathrm{td}, J$ $=7.2,5.6 \mathrm{~Hz}, 2 \mathrm{H}), 1.87-1.61(\mathrm{~m}, 2 \mathrm{H}), 1.47-1.39(\mathrm{~m}, 2 \mathrm{H}), 1.38-1.32$ (m, 4H), 0.96-0.87 (m, 3H). ${ }^{13} \mathrm{C}$ NMR $\left(101 \mathrm{MHz}, \mathrm{CDCl}_{3}\right) \delta 154.26$ (C), 152.36 (CO), 143.05 (C), 130.01 (C), $124.31(\mathrm{CH}), 120.70$ (CH), $117.52(\mathrm{CH}), 110.10(\mathrm{CH}), 41.15\left(\mathrm{CH}_{2}\right), 31.54\left(\mathrm{CH}_{2}\right), 29.61$ $\left(\mathrm{CH}_{2}\right), 26.74\left(\mathrm{CH}_{2}\right), 22.67\left(\mathrm{CH}_{2}\right), 14.13\left(\mathrm{CH}_{3}\right)$. qNMR: $96.2 \%$. 
Synthesis of 2-Amino- $N$-(4-phenylbutyl)benzimidazole-1-carboxamide (8). Compound 8 was synthesized following the general procedure previously described using 2 -aminobenzimidazole $(152.0$ $\mathrm{mg}, 1.11 \mathrm{mmol})$ and 4-phenylbutyl isocyanate $(0.098 \mathrm{~mL}, 0.55 \mathrm{mmol})$. Purification by typical silica gel flash chromatography (cyclohexane/ AcOEt from 60:40 to 30:70) and final trituration in diethyl ether twice $(2 \times 1 \mathrm{~mL})$ afforded $8(109 \mathrm{mg}, 64 \%)$ as a white solid. $\mathrm{Rt}=2.47 \mathrm{~min}$ (analysis method 1). MS (ESI) $m / z: 309.2[\mathrm{M}-\mathrm{H}]^{+}$, calculated 309.2. ${ }^{1} \mathrm{H}$ NMR $\left(400 \mathrm{MHz}, \mathrm{CDCl}_{3}\right) \delta 7.40(\mathrm{~d}, J=7.7 \mathrm{~Hz}, 1 \mathrm{H}), 7.33-$ $7.27(\mathrm{~m}, 2 \mathrm{H}), 7.25-7.15(\mathrm{~m}, 5 \mathrm{H}), 7.07(\mathrm{td}, J=7.7,1.1 \mathrm{~Hz}, 1 \mathrm{H}), 6.11$ $(\mathrm{s}, 2 \mathrm{H}), 5.86(\mathrm{~s}, 1 \mathrm{H}), 3.50(\mathrm{q}, J=6.6 \mathrm{~Hz}, 2 \mathrm{H}), 2.70(\mathrm{t}, J=7.0 \mathrm{~Hz}$, $2 \mathrm{H}), 1.91-1.58(\mathrm{~m}, 4 \mathrm{H}) .{ }^{13} \mathrm{C}$ NMR $\left(101 \mathrm{MHz}, \mathrm{CDCl}_{3}\right) \delta 154.23(\mathrm{C})$, $152.39(\mathrm{CO}), 141.84(\mathrm{C}), 129.95(\mathrm{C}), 128.61(\mathrm{CH}), 128.54(\mathrm{CH})$, $126.16(\mathrm{CH}), 124.33(\mathrm{CH}), 120.71(\mathrm{CH}), 117.52(\mathrm{CH}), 110.12$ $(\mathrm{CH}), 40.94\left(\mathrm{CH}_{2}\right), 35.53\left(\mathrm{CH}_{2}\right), 29.19\left(\mathrm{CH}_{2}\right), 28.77\left(\mathrm{CH}_{2}\right)$. qNMR: $96.3 \%$.

Synthesis of $\mathrm{N}$-Hexylbenzimidazole-1-carboxamide (9). Compound 9 was synthesized following the general procedure previously described using benzimidazole (100 $\mathrm{mg}, 0.84 \mathrm{mmol})$ and hexyl isocyanate $(0.13 \mathrm{~mL}, 0.84 \mathrm{mmol})$. Purification by typical silica gel flash chromatography (cyclohexane/TBME from 60:40 to 30:70) and final trituration in diethyl ether twice $(2 \times 1 \mathrm{~mL})$ afforded $9(41 \mathrm{mg}, 20 \%)$ as a white solid. Rt $=2.53 \mathrm{~min}$ (analysis method 1 ). MS (ESI) $\mathrm{m} / \mathrm{z}$ : 246.2 $[\mathrm{M}-\mathrm{H}]^{+}$, calculated 246.2. ${ }^{1} \mathrm{H}$ NMR $\left(400 \mathrm{MHz}, \mathrm{CDCl}_{3}\right) \delta$ $8.43(\mathrm{~s}, 1 \mathrm{H}), 7.89-7.82(\mathrm{~m}, 1 \mathrm{H}), 7.80-7.77(\mathrm{~m}, 1 \mathrm{H}), 7.43-7.32(\mathrm{~m}$, $2 \mathrm{H}), 6.27(\mathrm{~s}, 1 \mathrm{H}), 3.50(\mathrm{td}, J=7.3,5.7 \mathrm{~Hz}, 2 \mathrm{H}), 1.78-1.59(\mathrm{~m}, 2 \mathrm{H})$, $1.47-1.36(\mathrm{~m}, 2 \mathrm{H}), 1.33(\mathrm{~m}, 4 \mathrm{H}), 1.01-0.80(\mathrm{~m}, 3 \mathrm{H}) .{ }^{13} \mathrm{C}$ NMR $\left(101 \mathrm{MHz}, \mathrm{CDCl}_{3}\right) \delta 149.72(\mathrm{CO}), 143.27(\mathrm{C}), 141.20(\mathrm{CH}), 131.92$ (C), $124.36(\mathrm{CH}), 123.38(\mathrm{CH}), 119.78(\mathrm{CH}), 114.37(\mathrm{CH}), 40.19$ $\left(\mathrm{CH}_{2}\right), 30.97\left(\mathrm{CH}_{2}\right), 28.88\left(\mathrm{CH}_{2}\right), 26.02\left(\mathrm{CH}_{2}\right), 22.05\left(\mathrm{CH}_{2}\right), 13.91$ $\left(\mathrm{CH}_{3}\right)$. qNMR: $96.1 \%$.

Synthesis of $\mathrm{N}$-(4-Phenylbutyl)benzimidazole-1-carboxamide (10). Compound 10 was synthesized following the general procedure previously described using benzimidazole $(100.0 \mathrm{mg}, 0.84 \mathrm{mmol})$ and 4-phenylbutyl isocyanate $(0.15 \mathrm{~mL}, 0.84 \mathrm{mmol})$. Purification by typical silica gel flash chromatography (cyclohexane/AcOEt from 90:10 to $60: 40)$ and final trituration in diethyl ether twice $(2 \times 1 \mathrm{~mL})$ afforded $10(106 \mathrm{mg}, 43 \%)$ as a white solid. $\mathrm{Rt}=2.57 \mathrm{~min}$ (analysis method 1$)$. MS (ESI) $m / z: 294.2[\mathrm{M}-\mathrm{H}]^{+}$, calculated 294.2. ${ }^{1} \mathrm{H}$ NMR (400 MHz, DMSO-d 6 ) $\delta 8.70(\mathrm{~s}, 1 \mathrm{H}), 8.53(\mathrm{t}, J=5.5 \mathrm{~Hz}, 1 \mathrm{H}), 8.11-7.99$ $(\mathrm{m}, 1 \mathrm{H}), 7.76-7.66(\mathrm{~m}, 1 \mathrm{H}), 7.36(\mathrm{td}, J=7.7,1.5 \mathrm{~Hz}, 1 \mathrm{H}), 7.32(\mathrm{dd}, J$ $=7.7,1.5 \mathrm{~Hz}, 1 \mathrm{H}), 7.30-7.24(\mathrm{~m}, 2 \mathrm{H}), 7.23-7.13(\mathrm{~m}, 3 \mathrm{H}), 3.34(\mathrm{~m}$, $2 \mathrm{H}), 2.63(\mathrm{t}, J=7.2 \mathrm{~Hz}, 2 \mathrm{H}), 1.72-1.57(\mathrm{~m}, 4 \mathrm{H}) .{ }^{13} \mathrm{C}$ NMR $(101$ $\left.\mathrm{MHz}, \mathrm{DMSO}-d_{6}\right) \delta 149.73$ (CO), 143.25 (C), 142.02 (C), 141.20 $(\mathrm{CH}), 131.90(\mathrm{C}), 128.30(\mathrm{CH}), 128.23(\mathrm{CH}), 125.67(\mathrm{CH}), 124.36$ (CH), $123.37(\mathrm{CH}), 119.77(\mathrm{CH}), 114.35(\mathrm{CH}), 40.00\left(\mathrm{CH}_{2}\right), 34.77$ $\left(\mathrm{CH}_{2}\right), 28.56\left(\mathrm{CH}_{2}\right), 28.28\left(\mathrm{CH}_{2}\right)$. qNMR: $97.2 \%$.

Synthesis of $\mathrm{N}$-Hexylindazole-1-carboxamide (11). Compound 11 was synthesized following the general procedure previously described using indazole $(100 \mathrm{mg}, 0.84 \mathrm{mmol})$ and hexyl isocyanate $(0.13 \mathrm{~mL}$, $0.84 \mathrm{mmol}$ ). Purification by typical silica gel flash chromatography (cyclohexane/TBME from 100:0 to 80:20) and final trituration in diethyl ether twice $(2 \times 1 \mathrm{~mL})$ afforded $11(144 \mathrm{mg}, 70 \%)$ as a white solid. Rt $=1.82 \mathrm{~min}$ (analysis method 2). MS (ESI) $\mathrm{m} / z: 246.2[\mathrm{M}-$ $\mathrm{H}]^{+}$, calculated 246.2. ${ }^{1} \mathrm{H}$ NMR (400 MHz, DMSO- $\left.d_{6}\right) \delta 9.02(\mathrm{t}, J=$ $6.0 \mathrm{~Hz}, 1 \mathrm{H}), 8.90(\mathrm{~d}, J=1.1 \mathrm{~Hz}, 1 \mathrm{H}), 7.77(\mathrm{dt}, J=8.6,1.1 \mathrm{~Hz}, 1 \mathrm{H})$, $7.66(\mathrm{dq}, J=8.6,1.0 \mathrm{~Hz}, 1 \mathrm{H}), 7.37(\mathrm{ddd}, J=8.6,6.5,1.1 \mathrm{~Hz}, 1 \mathrm{H}), 7.12$ (ddd, $J=8.6,6.5,1.1 \mathrm{~Hz}, 1 \mathrm{H}), 3.33-3.28(\mathrm{~m}, 2 \mathrm{H}), 1.58(\mathrm{q}, J=7.2 \mathrm{~Hz}$, $2 \mathrm{H}), 1.38-1.21(\mathrm{~m}, 6 \mathrm{H}), 0.91-0.80(\mathrm{~m}, 3 \mathrm{H}) .{ }^{13} \mathrm{C} \mathrm{NMR}(101 \mathrm{MHz}$, DMSO- $\left.d_{6}\right) \delta 149.72(\mathrm{CO}), 148.86(\mathrm{C}), 128.54(\mathrm{CH}), 122.89(\mathrm{CH})$, $122.82(\mathrm{CH}), 121.99(\mathrm{C}), 121.47(\mathrm{CH}), 117.72(\mathrm{CH}), 39.94\left(\mathrm{CH}_{2}\right)$, $30.92\left(\mathrm{CH}_{2}\right), 28.86\left(\mathrm{CH}_{2}\right), 25.91\left(\mathrm{CH}_{2}\right), 22.02\left(\mathrm{CH}_{2}\right), 13.89\left(\mathrm{CH}_{3}\right)$. qNMR: $98.5 \%$.

Synthesis of $\mathrm{N}$-(4-Phenylbutyl)indazole-1-carboxamide (12). Compound 12 was synthesized following the general procedure previously described using indazole $(100.0 \mathrm{mg}, 0.84 \mathrm{mmol})$ and $4-$ phenylbutyl isocyanate $(0.15 \mathrm{~mL}, 0.84 \mathrm{mmol})$. Purification by typical silica gel flash chromatography (cyclohexane/TBME from 100:0 to $80: 20)$ and final trituration in diethyl ether twice $(2 \times 1 \mathrm{~mL})$ afforded $12(150 \mathrm{mg}, 61 \%)$ as a white solid. $\mathrm{Rt}=1.80 \mathrm{~min}$ (analysis method 2$)$.
MS (ESI) $m / z: 294.2[\mathrm{M}-\mathrm{H}]^{+}$, calculated 294.2. ${ }^{1} \mathrm{H}$ NMR (400 MHz, DMSO- $\left.d_{6}\right) \delta 9.07(\mathrm{t}, J=6.0 \mathrm{~Hz}, 1 \mathrm{H}), 8.90(\mathrm{~s}, 1 \mathrm{H}), 7.77(\mathrm{~d}, J=$ $8.6 \mathrm{~Hz}, 1 \mathrm{H}), 7.65(\mathrm{~d}, J=8.9 \mathrm{~Hz}, 1 \mathrm{H}), 7.37(\mathrm{dd} J=8.9,6.6 \mathrm{~Hz}, 1 \mathrm{H})$, $7.26(\mathrm{t}, J=7.5 \mathrm{~Hz}, 2 \mathrm{H}), 7.21-7.09(\mathrm{~m}, 4 \mathrm{H}), 3.37(\mathrm{~m}, 2 \mathrm{H}), 2.66-2.56$ $(\mathrm{m}, 2 \mathrm{H}), 1.62(\mathrm{~m}, 4 \mathrm{H}) .{ }^{13} \mathrm{C}$ NMR (101 MHz, DMSO-d $\left.d_{6}\right) \delta 149.76$ (CO), $148.86(\mathrm{C}), 142.07(\mathrm{C}), 128.54(\mathrm{CH}), 128.29(\mathrm{CH}), 128.20$ $(\mathrm{CH}), 125.63(\mathrm{CH}), 122.89(\mathrm{CH}), 122.83(\mathrm{C}), 121.98(\mathrm{CH}), 121.46$ $(\mathrm{CH}), 117.71(\mathrm{CH}), 39.75\left(\mathrm{CH}_{2}\right), 34.75\left(\mathrm{CH}_{2}\right), 28.59\left(\mathrm{CH}_{2}\right), 28.29$ $\left(\mathrm{CH}_{2}\right)$. qNMR: $97.3 \%$.

Synthesis of N-Hexylbenzotriazole-1-carboxamide (13). Compound 13 was synthesized following the general procedure previously described using benzotriazole $(50 \mathrm{mg}, 0.42 \mathrm{mmol}$ ) and hexyl isocyanate $(0.06 \mathrm{~mL}, 0.42 \mathrm{mmol})$. Purification by typical silica gel flash chromatography (cyclohexane/TBME from 100:0 to 70:30) and final trituration in diethyl ether twice $(2 \times 1 \mathrm{~mL})$ afforded $13(65 \mathrm{mg}$, $64 \%)$ as a white solid. $\mathrm{Rt}=2.92 \mathrm{~min}$ (analysis method 1). MS (ESI) $m / z: 247.1[\mathrm{M}-\mathrm{H}]^{+}$, calculated 247.2. ${ }^{1} \mathrm{H} \mathrm{NMR}\left(400 \mathrm{MHz}, \mathrm{CDCl}_{3}\right)$ $\delta 8.29(\mathrm{~d}, J=8.3 \mathrm{~Hz}, 1 \mathrm{H}), 8.09(\mathrm{~d}, J=8.3 \mathrm{~Hz}, 1 \mathrm{H}), 7.62(\mathrm{ddd}, J=8.3$, 7.1, $1.0 \mathrm{~Hz}, 1 \mathrm{H}), 7.46$ (ddd, $J=8.3,7.1,1.0 \mathrm{~Hz}, 1 \mathrm{H}), 7.30(\mathrm{~s}, 1 \mathrm{H})$, $3.55(\mathrm{td}, J=7.2,5.9 \mathrm{~Hz}, 2 \mathrm{H}), 1.97-1.61(\mathrm{~m}, 2 \mathrm{H}), 1.41-1.47(\mathrm{~m}, 2 \mathrm{H})$, 1.39-1.32 (m, 4H), 1.03-0.77 (m, 3H). ${ }^{13} \mathrm{C}$ NMR (101 MHz, $\left.\mathrm{CDCl}_{3}\right) \delta 149.39(\mathrm{CO}), 146.46(\mathrm{C}), 131.82(\mathrm{C}), 130.02(\mathrm{CH}), 125.51$ $(\mathrm{CH}), 120.12(\mathrm{CH}), 114.14(\mathrm{CH}), 40.74\left(\mathrm{CH}_{2}\right), 31.57\left(\mathrm{CH}_{2}\right), 29.70$ $\left(\mathrm{CH}_{2}\right), 26.64\left(\mathrm{CH}_{2}\right), 22.68\left(\mathrm{CH}_{2}\right), 14.15\left(\mathrm{CH}_{3}\right)$. qNMR: $96.3 \%$.

Synthesis of $\mathrm{N}$-(4-Phenylbutyl)benzotriazole-1-carboxamide (14). Compound 14 was synthesized following the general procedure previously described using benzotriazole $(50 \mathrm{mg}, 0.42 \mathrm{mmol})$ and $4-$ phenylbutyl isocyanate $(0.08 \mathrm{~mL}, 0.42 \mathrm{mmol})$. Purification by typical silica gel flash chromatography (cyclohexane/TBME from 100:0 to $70: 30)$ and final trituration in diethyl ether twice $(2 \times 1 \mathrm{~mL})$ afforded $14(78 \mathrm{mg}, 64 \%)$ as a white solid. Rt $=2.91 \mathrm{~min}$ (analysis method 1$)$. MS (ESI) $\mathrm{m} / \mathrm{z}: 295.1[\mathrm{M}-\mathrm{H}]^{+}$, calculated 295.2. ${ }^{1} \mathrm{H}$ NMR (400 $\left.\mathrm{MHz}, \mathrm{CDCl}_{3}\right) \delta 8.28(\mathrm{dt}, J=8.3,1.0 \mathrm{~Hz}, 1 \mathrm{H}), 8.09(\mathrm{dt}, J=8.3,1.0 \mathrm{~Hz}$, $1 \mathrm{H}), 7.63$ (ddd, $J=8.3,7.0,1.0 \mathrm{~Hz}, 1 \mathrm{H}), 7.46$ (ddd, $J=8.3,7.0,1.0$ $\mathrm{Hz}, 1 \mathrm{H}), 7.33-7.26(\mathrm{~m}, 3 \mathrm{H}), 7.22-7.15(\mathrm{~m}, 2 \mathrm{H}), 3.57(\mathrm{q}, J=6.5 \mathrm{~Hz}$, $2 \mathrm{H}), 2.70(\mathrm{t}, J=7.0 \mathrm{~Hz}, 2 \mathrm{H}), 1.81-1.73(\mathrm{~m}, 4 \mathrm{H}) .{ }^{13} \mathrm{C} \mathrm{NMR}(101$ $\left.\mathrm{MHz}, \mathrm{CDCl}_{3}\right) \delta 149.39$ (CO), 146.45 (C), 141.93 (C), 131.80 (C), $130.05(\mathrm{CH}), 128.55(\mathrm{CH}), 126.08(\mathrm{CH}), 125.53(\mathrm{CH}), 120.13$ $(\mathrm{CH}), 114.12(\mathrm{CH}), 40.54\left(\mathrm{CH}_{2}\right), 35.59\left(\mathrm{CH}_{2}\right), 29.33\left(\mathrm{CH}_{2}\right), 28.69$ $\left(\mathrm{CH}_{2}\right)$. qNMR: $95.7 \%$.

Synthesis of N-Hexyltriazolo[4,5-b]pyridine-1-carboxamide (15). Compound 15 was synthesized following the general procedure previously described using $1 \mathrm{H}-1,2,3$-triazolo $[4,5-b]$ pyridine $(50 \mathrm{mg}$, $0.41 \mathrm{mmol})$ and hexyl isocyanate $(0.06 \mathrm{~mL}, 0.42 \mathrm{mmol})$. Purification by typical silica gel flash chromatography (cyclohexane/TBME from $90: 10$ to $60: 40)$ and final trituration in diethyl ether twice $(2 \times 1 \mathrm{~mL})$ afforded $15(62 \mathrm{mg}, 61 \%)$ as a white solid. $\mathrm{Rt}=2.50 \mathrm{~min}$ (analysis method 1). MS (ESI) $m / z: 248.1[\mathrm{M}-\mathrm{H}]^{+}$, calculated $248.2 .{ }^{1} \mathrm{H}$ NMR $\left(400 \mathrm{MHz}, \mathrm{CDCl}_{3}\right) \delta 8.82(\mathrm{dd}, J=4.4,1.6 \mathrm{~Hz}, 1 \mathrm{H}), 8.63(\mathrm{dd}, J$ $=8.3,1.6 \mathrm{~Hz}, 1 \mathrm{H}), 7.58(\mathrm{dd}, J=8.3,4.4 \mathrm{~Hz}, 1 \mathrm{H}), 7.32(\mathrm{~s}, 1 \mathrm{H}), 3.64-$ $3.48(\mathrm{~m}, 2 \mathrm{H}), 1.80-1.63(\mathrm{~m}, 2 \mathrm{H}), 1.50-1.40(\mathrm{~m}, 2 \mathrm{H}), 1.42-1.27(\mathrm{~m}$ $1 \mathrm{H}), 1.01-0.79(\mathrm{~m}, 3 \mathrm{H}) .{ }^{13} \mathrm{C}$ NMR $\left(101 \mathrm{MHz}, \mathrm{CDCl}_{3}\right) \delta 157.86$ (CO), $149.51(\mathrm{CH}), 148.71(\mathrm{C}), 124.71(\mathrm{C}), 124.50(\mathrm{CH}), 123.11$ $(\mathrm{CH}), 40.86\left(\mathrm{CH}_{2}\right), 31.53\left(\mathrm{CH}_{2}\right), 29.61\left(\mathrm{CH}_{2}\right), 26.60\left(\mathrm{CH}_{2}\right), 22.67$ $\left(\mathrm{CH}_{2}\right), 14.13\left(\mathrm{CH}_{3}\right)$. qNMR: $97.2 \%$.

Synthesis of N-(4-Phenylbutyl)triazolo[4,5-b]pyridine-1-carboxamide (16). Compound 16 was synthesized following the general procedure previously described using $1 H$-1,2,3-triazolo[4,5-b] pyridine $(50 \mathrm{mg}, 0.41 \mathrm{mmol})$ and 4-phenylbutyl isocyanate $(0.07 \mathrm{~mL}, 0.41$ mmol). Purification by typical silica gel flash chromatography (cyclohexane/TBME from 100:0 to 70:30) and final trituration in diethyl ether twice $(2 \times 1 \mathrm{~mL})$ afforded $16(75 \mathrm{mg}, 62 \%)$ as a white solid. Rt $=2.53 \mathrm{~min}$ (analysis method 1). MS (ESI) m/z: $296.1[\mathrm{M}-$ $\mathrm{H}]^{+}$, calculated 296.2. ${ }^{1} \mathrm{H}$ NMR $\left(400 \mathrm{MHz}, \mathrm{CDCl}_{3}\right) \delta 8.82(\mathrm{dd}, J=$ $4.4,1.6 \mathrm{~Hz}, 1 \mathrm{H}), 8.62(\mathrm{dd}, J=8.3,1.6 \mathrm{~Hz}, 1 \mathrm{H}), 7.58(\mathrm{dd}, J=8.3,4.4$ $\mathrm{Hz}, 1 \mathrm{H}), 7.35-7.26(\mathrm{~m}, 3 \mathrm{H}), 7.23-7.15(\mathrm{~m}, 2 \mathrm{H}), 3.58(\mathrm{q}, J=6.5 \mathrm{~Hz}$, $2 \mathrm{H}), 2.70(\mathrm{t}, J=6.9 \mathrm{~Hz}, 2 \mathrm{H}), 1.84-1.71(\mathrm{~m}, 4 \mathrm{H}) .{ }^{13} \mathrm{C}$ NMR $(101$ $\left.\mathrm{MHz}, \mathrm{CDCl}_{3}\right) \delta 157.85(\mathrm{C}), 149.52(\mathrm{CH}), 148.72(\mathrm{C}), 141.82(\mathrm{CO})$, $128.57(\mathrm{CH}), 128.53(\mathrm{CH}), 126.12(\mathrm{CH}), 124.69(\mathrm{C}), 124.52(\mathrm{CH})$, 
$123.09(\mathrm{CH}), 40.67\left(\mathrm{CH}_{2}\right), 35.56\left(\mathrm{CH}_{2}\right), 29.24\left(\mathrm{CH}_{2}\right), 28.65\left(\mathrm{CH}_{2}\right)$. qNMR: $96.1 \%$.

$\mathrm{N}$-Hexyl-1,3-dioxo-isoindoline-2-carboxamide (17). Compound 17 was synthesized following the general procedure previously described using isoindoline-1,3-dione $(300 \mathrm{mg}, 2.0 \mathrm{mmol})$ and hexyl isocyanate $(0.15 \mathrm{~mL}, 0.5 \mathrm{mmol})$. Purification by typical silica gel flash chromatography (cyclohexane/TBME from 100:0 to 60:40) and final trituration in diethyl ether twice $(2 \times 1 \mathrm{~mL})$ afforded $17(105 \mathrm{mg}$, $38 \%$ ) as a white solid. Rt $=2.53$ min (analysis method 1). MS (ESI) $m / z: 275.2[\mathrm{M}-\mathrm{H}]^{+}$, calculated 275.1. ${ }^{1} \mathrm{H}$ NMR $(400 \mathrm{MHz}$, DMSO$\left.d_{6}\right) \delta 8.42(\mathrm{t}, J=5.7 \mathrm{~Hz}, 1 \mathrm{H}), 8.04-7.82(\mathrm{~m}, 4 \mathrm{H}), 3.26-3.17(\mathrm{~m}, 2 \mathrm{H})$, $1.60-1.43(\mathrm{~m}, 2 \mathrm{H}), 1.42-1.18(\mathrm{~m}, 6 \mathrm{H}), 0.96-0.82(\mathrm{~m}, 3 \mathrm{H}) .{ }^{13} \mathrm{C}$ NMR (101 MHz, DMSO-d $\left.d_{6}\right) \delta 165.40$ (CO), 147.45 (CO), 135.24 $(\mathrm{CH}), 131.06(\mathrm{C}), 123.81(\mathrm{CH}), 40.08\left(\mathrm{CH}_{2}\right), 30.86\left(\mathrm{CH}_{2}\right), 28.56$ $\left(\mathrm{CH}_{2}\right), 25.73\left(\mathrm{CH}_{2}\right), 22.04\left(\mathrm{CH}_{2}\right), 13.90\left(\mathrm{CH}_{3}\right)$. qNMR: $96.3 \%$.

Synthesis of 1,3-Dioxo- $N$-(4-phenylbutyl)isoindoline-2-carboxamide (18). Compound 18 was synthesized following the general procedure previously described using isoindoline-1,3-dione $(300 \mathrm{mg}$, $2.0 \mathrm{mmol})$ and 4-phenylbutyl isocyanate $(0.18 \mathrm{~mL}, 1.0 \mathrm{mmol})$. Purification by typical silica gel flash chromatography (cyclohexane/ TBME from 100:0 to 70:30) and final trituration in diethyl ether twice $(2 \times 1 \mathrm{~mL})$ afforded $18(39 \mathrm{mg}, 12 \%)$ as a white solid. $\mathrm{Rt}=2.59 \mathrm{~min}$ (analysis method 1). MS (ESI) $m / z: 323.2[\mathrm{M}-\mathrm{H}]^{+}$, calculated 323.1. ${ }^{1} \mathrm{H}$ NMR (400 MHz, DMSO- $\left.d_{6}\right) \delta 8.45(\mathrm{t}, J=5.8 \mathrm{~Hz}, 1 \mathrm{H})$, 8.05-7.87 (m, 4H), 7.32-7.25 (m, 2H), 7.24-7.19 (m, 2H), 7.20$7.14(\mathrm{~m}, 1 \mathrm{H}), 3.26(\mathrm{q}, J=6.5 \mathrm{~Hz}, 2 \mathrm{H}), 2.61(\mathrm{t}, J=7.6 \mathrm{~Hz}, 2 \mathrm{H}), 1.76-$ $1.56(\mathrm{~m}, 2 \mathrm{H}), 1.59-1.44(\mathrm{~m}, 2 \mathrm{H}) .{ }^{13} \mathrm{C}$ NMR $\left(101 \mathrm{MHz}, \mathrm{DMSO}-d_{6}\right) \delta$ 165.39 (CO), 162.72 (CO), 147.47 (C), $142.02(\mathrm{C}), 135.25(\mathrm{CH})$, $131.05(\mathrm{CH}), 128.28(\mathrm{C}), 128.24(\mathrm{CH}), 125.67(\mathrm{CH}), 123.82(\mathrm{CH})$, $39.87\left(\mathrm{CH}_{2}\right), 34.68\left(\mathrm{CH}_{2}\right), 28.27\left(\mathrm{CH}_{2}\right), 27.99\left(\mathrm{CH}_{2}\right)$. qNMR: $96.5 \%$.

Synthesis of 2-Oxo- $\mathrm{N}$-(4-phenylbutyl)-3H-benzimidazole-1-carboxamide (19). Compound 19 was synthesized following the general procedure previously described using 1,3-dihydrobenzimidazol-2-one $(52 \mathrm{mg}, 0.39 \mathrm{mmol})$ and 4-phenylbutyl isocyanate $(0.03 \mathrm{~mL}, 0.19$ $\mathrm{mmol}$ ). Purification by typical silica gel flash chromatography (cyclohexane/AcOEt from 100:0 to 85:15) and final trituration in diethyl ether twice $(2 \times 1 \mathrm{~mL})$ afforded $19(14 \mathrm{mg}, 23 \%)$ as a white solid. Rt $=1.28 \mathrm{~min}$ (analysis method 1). MS (ESI) $\mathrm{m} / z: 310.2[\mathrm{M}-$ $\mathrm{H}]^{+}$, calculated 310.2. ${ }^{1} \mathrm{H}$ NMR $\left(400 \mathrm{MHz}, \mathrm{CDCl}_{3}\right) \delta 8.65(\mathrm{~s}, 2 \mathrm{H})$, $8.21(\mathrm{dd}, J=6.0,3.3 \mathrm{~Hz}, 1 \mathrm{H}), 7.29(\mathrm{~d}, J=7.7 \mathrm{~Hz}, 1 \mathrm{H}), 7.22-7.14(\mathrm{~m}$, $6 \mathrm{H}), 7.08-7.02(\mathrm{~m}, 1 \mathrm{H}), 3.46(\mathrm{q}, J=6.6 \mathrm{~Hz}, 2 \mathrm{H}), 2.68(\mathrm{t}, J=7.2 \mathrm{~Hz}$, $2 \mathrm{H}), 1.80-1.63(\mathrm{~m}, 4 \mathrm{H}) .{ }^{13} \mathrm{C}$ NMR $\left(101 \mathrm{MHz}, \mathrm{CDCl}_{3}\right) \delta 154.50$ (CO), 151.80 (CO), 142.20 (C), $128.54(\mathrm{CH}), 128.48(\mathrm{C}), 127.88$ (C), $126.84(\mathrm{CH}), 125.96(\mathrm{CH}), 123.99(\mathrm{CH}), 123.10(\mathrm{CH}), 115.74$ (CH), $109.39(\mathrm{CH}), 39.96\left(\mathrm{CH}_{2}\right), 35.66\left(\mathrm{CH}_{2}\right), 29.37\left(\mathrm{CH}_{2}\right), 28.84$ $\left(\mathrm{CH}_{2}\right)$. qNMR: $97.1 \%$.

Synthesis of 2-Oxo-N1,N3-bis(4-phenylbutyl)benzimidazole-1,3dicarboxamide (20). Compound 20 was synthesized following the general procedure previously described using 1,3-dihydrobenzimidazol-2-one $(30 \mathrm{mg}, 0.22 \mathrm{mmol})$ and 4-phenylbutyl isocyanate $(0.08 \mathrm{~mL}$, $0.45 \mathrm{mmol}$ ). Purification by typical silica gel flash chromatography (cyclohexane/TBME from 100:0 to 80:20) and final trituration in diethyl ether twice $(2 \times 1 \mathrm{~mL})$ afforded $20(61 \mathrm{mg}, 56 \%)$ as a white solid. Rt $=2.77 \mathrm{~min}$ (analysis method 2). MS (ESI) $\mathrm{m} / z: 485.2[\mathrm{M}-$ $\mathrm{H}]^{+}$, calculated: 485.3. ${ }^{1} \mathrm{H} \mathrm{NMR}\left(400 \mathrm{MHz}, \mathrm{CDCl}_{3}\right) \delta 8.43(\mathrm{t}, J=5.4$ $\mathrm{Hz}, 2 \mathrm{H}), 8.30$ (dd, $J=6.1,3.4 \mathrm{~Hz}, 2 \mathrm{H}), 7.34-7.26(\mathrm{~m}, 6 \mathrm{H}), 7.20(\mathrm{~d}, J$ $=7.1 \mathrm{~Hz}, 2 \mathrm{H}), 3.49(\mathrm{q}, J=6.6 \mathrm{~Hz}, 2 \mathrm{H}), 2.71(\mathrm{t}, J=7.2 \mathrm{~Hz}, 1 \mathrm{H})$, $1.81-1.65(\mathrm{~m}, 8 \mathrm{H}) .{ }^{13} \mathrm{C}$ NMR $\left(101 \mathrm{MHz}, \mathrm{CDCl}_{3}\right) \delta 153.03(\mathrm{CO})$, $150.56(\mathrm{CO}), 141.78(\mathrm{C}), 128.24(\mathrm{C}), 128.19(\mathrm{CH}), 126.06(\mathrm{CH})$, $125.70(\mathrm{CH}), 124.58(\mathrm{CH}), 114.85(\mathrm{CH}), 39.87\left(\mathrm{CH}_{2}\right), 35.31\left(\mathrm{CH}_{2}\right)$, $28.91\left(\mathrm{CH}_{2}\right), 28.45\left(\mathrm{CH}_{2}\right)$. qNMR: $97.1 \%$.

Synthesis of 2-Methoxy-N-(4-phenylbutyl)benzimidazole-1-carboxamide (21). Step 1. Synthesis of 2-Methoxy-1H-benzimidazole (34). Under Ar atmosphere, a mixture of $o$-phenylenediamine $(500 \mathrm{mg}$, $4.53 \mathrm{mmol})$ and tetramethylorthocarbonate $(0.89 \mathrm{~mL}, 6.34 \mathrm{mmol})$ was stirred at $90{ }^{\circ} \mathrm{C}$ for $24 \mathrm{~h}$. Afterward, the reaction crude was concentrated to dryness at low pressure and purification by typical silica gel flash chromatography (cyclohexane/TBME from 95:5 to 70:30) afforded $34(400 \mathrm{mg}, 60 \%)$ as a white solid. Rt $=1.27 \mathrm{~min}$ (analysis method 1). MS (ESI) $\mathrm{m} / z: 149.1[\mathrm{M}-\mathrm{H}]^{+}$, calculated
149.1. ${ }^{1} \mathrm{H}$ NMR (400 MHz, DMSO- $d_{6}$ ) $\delta 11.80(\mathrm{~s}, 1 \mathrm{H}), 7.42-7.28$ (m, 1H), 7.26-7.12 (m, 1H), 7.11-6.94 (m, 2H), $4.04(\mathrm{~s}, 3 \mathrm{H})$.

Step 2. 2-Methoxy-N-(4-phenylbutyl)benzimidazole-1-carboxamide (21). Compound 21 was synthesized following the general procedure previously described using $34(100 \mathrm{mg}, 0.65 \mathrm{mmol})$ and 4phenylbutyl isocyanate $(0.12 \mathrm{~mL}, 0.65 \mathrm{mmol})$. Purification by typical silica gel flash chromatography (cyclohexane/AcOEt from 95:5 to $75: 25)$ and final trituration in diethyl ether twice $(2 \times 1 \mathrm{~mL})$ afforded 21 (95 mg, 45\%) as a white solid. Rt $=2.49 \mathrm{~min}$ (analysis method 1$)$. MS (ESI) $m / z: 324.1[\mathrm{M}-\mathrm{H}]^{+}$, calculated 324.2. ${ }^{1} \mathrm{H}$ NMR (400 $\left.\mathrm{MHz}, \mathrm{CDCl}_{3}\right) \delta 8.11-8.04(\mathrm{~m}, 1 \mathrm{H}), 7.45-7.37(\mathrm{~m}, 1 \mathrm{H}), 7.24-7.13$ $(\mathrm{m}, 4 \mathrm{H}), 7.13-7.07(\mathrm{~m}, 3 \mathrm{H}), 6.84(\mathrm{t}, J=6.2 \mathrm{~Hz}, 1 \mathrm{H}), 4.21(\mathrm{~s}, 3 \mathrm{H})$, $3.37(\mathrm{q}, J=6.6 \mathrm{~Hz}, 2 \mathrm{H}), 2.60(\mathrm{t}, J=7.1 \mathrm{~Hz}, 2 \mathrm{H}), 1.70-1.57(\mathrm{~m}, 3 \mathrm{H})$. ${ }^{13} \mathrm{C}$ NMR (101 MHz, $\left.\mathrm{CDCl}_{3}\right) \delta 154.78(\mathrm{CO}), 150.19(\mathrm{CO}), 142.07$ (C), $138.89(\mathrm{C}), 132.77(\mathrm{C}), 128.50(\mathrm{CH}), 126.01(\mathrm{CH}), 123.85$ $(\mathrm{CH}), 123.23(\mathrm{CH}), 117.79(\mathrm{CH}), 115.32(\mathrm{CH}), 58.60\left(\mathrm{OCH}_{3}\right)$, $40.48\left(\mathrm{CH}_{2}\right), 35.56\left(\mathrm{CH}_{2}\right), 29.28\left(\mathrm{CH}_{2}\right), 28.78\left(\mathrm{CH}_{2}\right)$. qNMR: $97.2 \%$.

Synthesis of 2-Methyl-N-(4-phenylbutyl)benzimidazole-1-carboxamide (22). Compound 22 was synthesized following the general procedure previously described using 2-mehthylbenzimidazole (100 $\mathrm{mg}, 0.75 \mathrm{mmol})$ and 4-phenylbutyl isocyanate $(0.13 \mathrm{~mL}, 0.75 \mathrm{mmol})$. Purification by typical silica gel flash chromatography (cyclohexane/ TBME from 50:50 to 30:70) and final trituration in diethyl ether twice $(2 \times 1 \mathrm{~mL})$ afforded $22(131 \mathrm{mg}, 57 \%)$ as a white solid. $\mathrm{Rt}=2.27 \mathrm{~min}$ (analysis method 1). MS (ESI) $m / z: 308.2[\mathrm{M}-\mathrm{H}]^{+}$, calculated 308.2. ${ }^{1} \mathrm{H}$ NMR $\left(400 \mathrm{MHz}, \mathrm{CDCl}_{3}\right) \delta 7.70-7.62(\mathrm{~m}, 1 \mathrm{H}), 7.51-7.44$ (m, 1H), 7.33-7.27 (m, 4H), 7.24-7.15 (m, 3H), $6.01(\mathrm{~s}, 1 \mathrm{H}), 3.54$ $(\mathrm{q}, J=6.4 \mathrm{~Hz}, 2 \mathrm{H}), 2.77(\mathrm{~s}, 3 \mathrm{H}), 2.72(\mathrm{t}, J=6.9 \mathrm{~Hz}, 2 \mathrm{H}), 1.89-1.68$ (m, 4H). ${ }^{13} \mathrm{C}$ NMR $\left(101 \mathrm{MHz}, \mathrm{CDCl}_{3}\right) \delta 152.58(\mathrm{CO}), 150.75$ (C), $142.73(\mathrm{C}), 141.83(\mathrm{C}), 132.57(\mathrm{C}), 128.60(\mathrm{CH}), 128.53(\mathrm{CH})$, $128.50(\mathrm{CH}), 126.16(\mathrm{CH}), 123.84(\mathrm{CH}), 120.03(\mathrm{CH}), 111.02$ $(\mathrm{CH}), 41.22\left(\mathrm{CH}_{2}\right), 35.53\left(\mathrm{CH}_{2}\right), 29.24\left(\mathrm{CH}_{2}\right), 28.81\left(\mathrm{CH}_{2}\right), 16.60$ $\left(\mathrm{CH}_{3}\right)$. qNMR: $96.1 \%$.

Synthesis of 2-Amino- $N$-benzyl-benzimidazole-1-carboxamide (23). Compound 23 was synthesized following the general procedure previously described using 2-aminobenzimidazole (100 mg, 0.74 $\mathrm{mmol}$ ) and benzyl isocyanate $(0.11 \mathrm{~mL}, 0.84 \mathrm{mmol})$. Purification by typical silica gel flash chromatography (cyclohexane/AcOEt from 80:20 to 40:60) followed by trituration in $\mathrm{Et}_{2} \mathrm{O}(5 \mathrm{~mL})$ afforded 23 $(125 \mathrm{mg}, 64 \%)$ as a white solid. $\mathrm{Rt}=1.83 \mathrm{~min}$ (analysis method 1 ). MS (ESI) $m / z: 267.1[\mathrm{M}-\mathrm{H}]^{+}$, calculated 267.1. ${ }^{1} \mathrm{H}$ NMR (400 $\left.\mathrm{MHz}, \mathrm{CDCl}_{3}\right) \delta 7.46-7.31(\mathrm{~m}, 5 \mathrm{H}), 7.29-7.25(\mathrm{~m}, 2 \mathrm{H}), 7.21(\mathrm{td}, J=$ $7.7,1.0 \mathrm{~Hz}, 1 \mathrm{H}), 7.05(\mathrm{td}, J=7.7,1.0 \mathrm{~Hz}, 1 \mathrm{H}), 6.24(\mathrm{bs}, 1 \mathrm{H}), 4.68(\mathrm{~d}$, $J=4.8 \mathrm{~Hz}, 2 \mathrm{H}) .{ }^{13} \mathrm{C}$ NMR $\left(101 \mathrm{MHz}, \mathrm{CDCl}_{3}\right) \delta 128.64(\mathrm{CH}), 128.61$ $(\mathrm{CH}), 125.43(\mathrm{CH}), 121.42(\mathrm{CH}), 117.86(\mathrm{CH}), 110.75(\mathrm{CH}), 45.39$ $\left(\mathrm{CH}_{2}\right)$. qNMR: $95.8 \%$.

Synthesis of 2-Amino-N-(o-tolylmethyl)benzimidazole-1-carboxamide (24). Compound $\mathbf{2 4}$ was synthesized following the general procedure previously described using 2 -aminobenzimidazole $(100 \mathrm{mg}$, $0.74 \mathrm{mmol}$ ) and 2-methylbenzyl isocyanate $(0.11 \mathrm{~mL}, 0.74 \mathrm{mmol})$. Purification by typical silica gel flash chromatography (cyclohexane/ AcOEt from 70:30 to 50:50) followed by trituration in $\mathrm{Et}_{2} \mathrm{O}(5 \mathrm{~mL})$ afforded $24(120 \mathrm{mg}, 64 \%)$ as a white solid. $\mathrm{Rt}=1.97 \mathrm{~min}$ (analysis method 1). MS (ESI) $m / z: 281.1[\mathrm{M}-\mathrm{H}]^{+}$, calculated 281.4. ${ }^{1} \mathrm{H}$ NMR $\left(400 \mathrm{MHz}, \mathrm{CDCl}_{3}\right) \delta 7.39(\mathrm{~d}, J=8.1 \mathrm{~Hz}, 1 \mathrm{H}), 7.34(\mathrm{~d}, J=7.1$ $\mathrm{Hz}, 1 \mathrm{H}), 7.30-7.24(\mathrm{~m}, J=6.1 \mathrm{~Hz}, 3 \mathrm{H}), 7.24-7.14(\mathrm{~m}, 2 \mathrm{H}), 7.02(\mathrm{t}, J$ $=7.7 \mathrm{~Hz}, 1 \mathrm{H}), 6.04(\mathrm{~s}, 1 \mathrm{H}), 4.67(\mathrm{~d}, J=4.3 \mathrm{~Hz}, 2 \mathrm{H}), 2.43(\mathrm{~s}, 3 \mathrm{H}) .{ }^{13} \mathrm{C}$ NMR $\left(101 \mathrm{MHz}, \mathrm{CDCl}_{3}\right) \delta 154.21\left(\mathrm{CNH}_{2}\right), 152.22(\mathrm{CO}), 136.49$ (C), 134.57 (C), $131.09(\mathrm{CH}), 129.86(\mathrm{C}), 128.73(\mathrm{CH}), 128.60$ $(\mathrm{CH}), 126.75(\mathrm{CH}), 124.42(\mathrm{CH}), 120.81(\mathrm{CH}), 117.53(\mathrm{CH})$, $110.09(\mathrm{CH}), 43.21\left(\mathrm{CH}_{2}\right), 19.28\left(\mathrm{CH}_{3}\right)$. qNMR: $95.2 \%$.

Synthesis of 2-Amino- $N$-(m-tolylmethyl)benzimidazole-1-carboxamide (25). Compound 25 was synthesized following the general procedure previously described using 2 -aminobenzimidazole $(100 \mathrm{mg}$, $0.74 \mathrm{mmol})$ and 3-methylbenzyl isocyanate $(0.10 \mathrm{~mL}, 0.74 \mathrm{mmol})$. Purification by typical silica gel flash chromatography (cyclohexane/ AcOEt from 85:15 to 65:35) followed by trituration in $\mathrm{Et}_{2} \mathrm{O}(5 \mathrm{~mL})$ afforded $25(65 \mathrm{mg}, 35 \%)$ as a white solid. $\mathrm{Rt}=0.97 \mathrm{~min}$ (analysis method 1). MS (ESI) $m / z: 281.1[\mathrm{M}-\mathrm{H}]^{+}$, calculated 281.4. ${ }^{1} \mathrm{H}$ NMR $\left(400 \mathrm{MHz}, \mathrm{CDCl}_{3}\right) \delta 7.39(\mathrm{~d}, J=7.8 \mathrm{~Hz}, 1 \mathrm{H}), 7.34-7.22(\mathrm{~m}$, 
2H), 7.23-7.14 (m, 4H), $7.03(\mathrm{t}, J=7.7 \mathrm{~Hz}, 1 \mathrm{H}), 6.19(\mathrm{~s}, 1 \mathrm{H}), 4.63$ $(\mathrm{d}, J=4.2 \mathrm{~Hz}, 2 \mathrm{H}), 2.38(\mathrm{~s}, 3 \mathrm{H}) .{ }^{13} \mathrm{C}$ NMR $\left(101 \mathrm{MHz}, \mathrm{CDCl}_{3}\right) \delta$ $154.25\left(\mathrm{CNH}_{2}\right), 152.37$ (CO), 142.99 (C), $139.04(\mathrm{C}), 136.87$ (C), $129.88(\mathrm{C}), 129.14(\mathrm{CH}), 129.07(\mathrm{CH}), 128.72(\mathrm{CH}), 124.96(\mathrm{CH})$, $124.41(\mathrm{CH}), 120.77(\mathrm{CH}), 117.49(\mathrm{CH}), 110.27(\mathrm{CH}), 45.12\left(\mathrm{CH}_{2}\right)$, $21.55\left(\mathrm{CH}_{3}\right)$. qNMR: $95.8 \%$.

Synthesis of 2-Amino- $\mathrm{N}$-(p-tolylmethyl)benzimidazole-1-carboxamide (26). Compound 26 was synthesized following the general procedure previously described using 2-aminobenzimidazole $(100 \mathrm{mg}$, $0.74 \mathrm{mmol}$ ) and 4-methylbenzyl isocyanate $(0.11 \mathrm{~mL}, 0.74 \mathrm{mmol})$. Purification by typical silica gel flash chromatography (cyclohexane/ AcOEt from 60:40 to 30:70) followed by trituration in $\mathrm{Et}_{2} \mathrm{O}(5 \mathrm{~mL})$ afforded $26(110 \mathrm{mg}, 60 \%)$ as a white solid. $\mathrm{Rt}=1.99 \mathrm{~min}$ (analysis method 1). MS (ESI) $m / z: 281.1[\mathrm{M}-\mathrm{H}]^{+}$, calculated 281.4. ${ }^{1} \mathrm{H}$ NMR (400 MHz, $\left.\mathrm{CDCl}_{3}\right) \delta 7.39(\mathrm{~d}, J=7.9 \mathrm{~Hz}, 1 \mathrm{H}), 7.28(\mathrm{t}, J=7.2$ $\mathrm{Hz}, 2 \mathrm{H}), 7.24-7.18(\mathrm{~m}, 4 \mathrm{H}), 7.08-7.01(\mathrm{~m}, 1 \mathrm{H}), 6.19(\mathrm{~s}, 1 \mathrm{H}), 4.63$ $(\mathrm{d}, J=4.7 \mathrm{~Hz}, 2 \mathrm{H}), 2.37(\mathrm{~s}, 3 \mathrm{H}) .{ }^{13} \mathrm{C}$ NMR $\left(101 \mathrm{MHz}, \mathrm{CDCl}_{3}\right) \delta$ $(\mathrm{CH}), 130.06(\mathrm{CH}), 128.10(\mathrm{CH}), 124.46(\mathrm{CH}), 121.27(\mathrm{CH})$, $117.60(\mathrm{CH}), 110.54(\mathrm{CH}), 45.08\left(\mathrm{CH}_{2}\right), 21.65\left(\mathrm{CH}_{3}\right)$. qNMR: 95.7\%.

Synthesis of N-Benzylbenzimidazole-1-carboxamide (27). Compound $\mathbf{2 7}$ was synthesized following the general procedure previously described using benzimidazole (100 $\mathrm{mg}, 0.84 \mathrm{mmol})$ and benzyl isocyanate $(0.11 \mathrm{~mL}, 0.84 \mathrm{mmol})$. Purification by typical silica gel flash chromatography (cyclohexane/AcOEt from 70:30 to 50:50) followed by trituration in $\mathrm{Et}_{2} \mathrm{O}(5 \mathrm{~mL})$ afforded $27(118 \mathrm{mg}, 56 \%)$ as a white solid. Rt $=1.95 \mathrm{~min}$ (analysis method 1). MS (ESI) $\mathrm{m} / z: 252.2[\mathrm{M}-$ $\mathrm{H}]^{+}$, calculated 252.1. ${ }^{1} \mathrm{H} \mathrm{NMR}\left(400 \mathrm{MHz}, \mathrm{CDCl}_{3}\right) \delta 8.47(\mathrm{~s}, 1 \mathrm{H})$, $7.85(\mathrm{dd}, J=7.2,1.6 \mathrm{~Hz}, 1 \mathrm{H}), 7.80(\mathrm{dd}, J=7.2,1.6 \mathrm{~Hz}, 1 \mathrm{H}), 7.46-$ $7.30(\mathrm{~m}, 7 \mathrm{H}), 6.36(\mathrm{t}, J=5.6 \mathrm{~Hz}, 1 \mathrm{H}), 4.70(\mathrm{~d}, J=5.6 \mathrm{~Hz}, 2 \mathrm{H}) .{ }^{13} \mathrm{C}$ NMR (101 MHz CDCl $)_{3} \delta 150.09(\mathrm{CO}), 144.17(\mathrm{C}), 140.93(\mathrm{CH})$, $137.13(\mathrm{C}), 131.33(\mathrm{C}), 129.18(\mathrm{CH}), 128.31(\mathrm{CH}), 128.12(\mathrm{CH})$, $125.33(\mathrm{CH}), 124.33(\mathrm{CH}), 121.01(\mathrm{CH}), 113.13(\mathrm{CH}), 45.27\left(\mathrm{CH}_{2}\right)$. qNMR: $96.2 \%$.

Synthesis of $\mathrm{N}$-(o-Tolylmethyl)benzimidazole-1-carboxamide (28). Compound 28 was synthesized following the general procedure previously described using benzimidazole $(100 \mathrm{mg}, 0.84 \mathrm{mmol})$ and 2methylbenzyl isocyanate $(0.12 \mathrm{~mL}, 0.84 \mathrm{mmol})$. Purification by typical silica gel flash chromatography (cyclohexane/AcOEt from 85:15 to 65:35) followed by trituration in $\mathrm{Et}_{2} \mathrm{O}(5 \mathrm{~mL})$ afforded $28(147 \mathrm{mg}$, $66 \%)$ as a white solid. $\mathrm{Rt}=2.07 \mathrm{~min}$ (analysis method 1 ). MS (ESI) $m / z: 266.1[\mathrm{M}-\mathrm{H}]^{+}$, calculated 266.1. ${ }^{1} \mathrm{H}$ NMR $\left(400 \mathrm{MHz}, \mathrm{CDCl}_{3}\right)$ $\delta 8.37(\mathrm{~s}, 1 \mathrm{H}), 7.83(\mathrm{dd}, J=7.2,1.8 \mathrm{~Hz}, 1 \mathrm{H}), 7.76(\mathrm{dd}, J=7.2,1.8 \mathrm{~Hz}$, $1 \mathrm{H}), 7.43-7.30(\mathrm{~m}, 4 \mathrm{H}), 7.28-7.17(\mathrm{~m}, 2 \mathrm{H}), 6.27(\mathrm{t}, J=5.2 \mathrm{~Hz}, 1 \mathrm{H})$, $4.69(\mathrm{~d}, J=5.2 \mathrm{~Hz}, 2 \mathrm{H}), 2.41(\mathrm{~s}, 4 \mathrm{H}) .{ }^{13} \mathrm{C} \mathrm{NMR}\left(101 \mathrm{MHz}, \mathrm{CDCl}_{3}\right) \delta$ 149.89 (CO), $144.15(\mathrm{C}), 140.87(\mathrm{CH}), 136.67(\mathrm{C}), 134.71(\mathrm{C})$, $131.34(\mathrm{C}), 131.03(\mathrm{CH}), 128.93(\mathrm{CH}), 128.58(\mathrm{CH}), 126.67(\mathrm{CH})$, $125.33(\mathrm{CH}), 124.32(\mathrm{CH}), 121.01(\mathrm{CH}), 113.08(\mathrm{CH}), 43.37\left(\mathrm{CH}_{2}\right)$, $19.27\left(\mathrm{CH}_{3}\right)$. qNMR: $95.7 \%$.

Synthesis of $\mathrm{N}$-(m-Tolylmethyl)benzimidazole-1-carboxamide (29). Compound 29 was synthesized following the general procedure previously described using benzimidazole $(100 \mathrm{mg}, 0.84 \mathrm{mmol})$ and 3methylbenzyl isocyanate $(0.12 \mathrm{~mL}, 0.84 \mathrm{mmol})$. Purification by typical silica gel flash chromatography (cyclohexane/AcOEt from 85:15 to 65:35) followed by trituration in $\mathrm{Et}_{2} \mathrm{O}(5 \mathrm{~mL})$ afforded $29(152 \mathrm{mg}$, $68 \%)$ as a white solid. Rt $=2.09 \mathrm{~min}$ (analysis method 1 ). MS (ESI) $\mathrm{m} / z: 266.1[\mathrm{M}-\mathrm{H}]^{+}$, calculated 266.1. ${ }^{1} \mathrm{H}$ NMR $\left(400 \mathrm{MHz}, \mathrm{CDCl}_{3}\right)$ $\delta 8.44(\mathrm{~s}, 1 \mathrm{H}), 7.86(\mathrm{dd}, J=7.5,1.7 \mathrm{~Hz}, 1 \mathrm{H}), 7.78(\mathrm{dd}, J=7.5,1.7 \mathrm{~Hz}$, $1 \mathrm{H}), 7.41-7.33(\mathrm{~m}, 2 \mathrm{H}), 7.32-7.24(\mathrm{~m}, 2 \mathrm{H}), 7.20(\mathrm{~d}, J=7.9 \mathrm{~Hz}$, $1 \mathrm{H}), 7.14(\mathrm{~d}, J=7.6 \mathrm{~Hz}, 1 \mathrm{H}), 6.34(\mathrm{t}, J=5.6 \mathrm{~Hz}, 1 \mathrm{H}), 4.65(\mathrm{~d}, J=5.6$ $\mathrm{Hz}, 2 \mathrm{H}), 2.36(\mathrm{~s}, 3 \mathrm{H}) .{ }^{13} \mathrm{C}$ NMR $\left(101 \mathrm{MHz}, \mathrm{CDCl}_{3}\right) \delta 150.03(\mathrm{CO})$, $144.21(\mathrm{C}), 140.95(\mathrm{CH}), 139.00$ (C), 137.02 (C), 131.32 (C), 129.09 $(\mathrm{CH}), 129.06(\mathrm{CH}), 128.88(\mathrm{CH}), 125.31(\mathrm{CH}), 125.13(\mathrm{CH})$, $124.32(\mathrm{CH}), 121.05(\mathrm{CH}), 113.09(\mathrm{CH}), 45.27\left(\mathrm{CH}_{2}\right), 21.53\left(\mathrm{CH}_{3}\right)$. qNMR: $97.3 \%$.

Synthesis of $\mathrm{N}$-(p-Tolylmethyl)benzimidazole-1-carboxamide (30). Compound 30 was synthesized following the general procedure previously described using benzimidazole $(100 \mathrm{mg}, 0.84 \mathrm{mmol})$ and 4methylbenzyl isocyanate $(0.12 \mathrm{~mL}, 0.84 \mathrm{mmol})$. Purification by typical silica gel flash chromatography (cyclohexane/AcOEt from 85:15 to
65:35) followed by trituration in $\mathrm{Et}_{2} \mathrm{O}(5 \mathrm{~mL})$ afforded $30(147 \mathrm{mg}$, $66 \%)$ as a white solid. Rt $=2.07$ min (analysis method 1$)$. MS (ESI) $m / z: 266.1[\mathrm{M}-\mathrm{H}]^{+}$, calculated $266.1{ }^{1} \mathrm{H}$ NMR $\left(400 \mathrm{MHz}, \mathrm{CDCl}_{3}\right)$ $\delta 8.41(\mathrm{~s}, 1 \mathrm{H}), 7.84(\mathrm{dd}, J=6.5,1.6 \mathrm{~Hz}, 1 \mathrm{H}), 7.75(\mathrm{dd}, J=6.5,1.6 \mathrm{~Hz}$, $1 \mathrm{H}), 7.41-7.31(\mathrm{~m}, 2 \mathrm{H}), 7.28(\mathrm{~d}, J=7.9 \mathrm{~Hz}, 2 \mathrm{H}), 7.18(\mathrm{~d}, J=7.9 \mathrm{~Hz}$, $2 \mathrm{H}), 6.45(\mathrm{t}, J=5.5 \mathrm{~Hz}, 1 \mathrm{H}), 4.63(\mathrm{~d}, J=5.5 \mathrm{~Hz}, 2 \mathrm{H}), 2.35(\mathrm{~s}, 3 \mathrm{H})$ ${ }^{13} \mathrm{C}$ NMR (101 MHz, $\left.\mathrm{CDCl}_{3}\right) \delta 150.09$ (CO), 143.87 (C), 140.86 $(\mathrm{CH}), 138.00(\mathrm{C}), 134.14(\mathrm{C}), 131.43(\mathrm{C}), 129.72(\mathrm{CH}), 128.05$ $(\mathrm{CH}), 125.25(\mathrm{CH}), 124.23(\mathrm{CH}), 120.67(\mathrm{CH}), 113.41(\mathrm{CH}), 44.95$ $\left(\mathrm{CH}_{2}\right), 21.24\left(\mathrm{CH}_{3}\right)$. qNMR: $96.1 \%$.

Coordinate Scan. We performed a force-field-based coordinate scan of the dihedral angle formed by $\mathrm{C} 2-\mathrm{N} 1-\mathrm{Cl}^{\prime}-\mathrm{Ol}^{\prime}$ atoms of the most promising compounds 8, 10, and 19-22. To do this, we used the coordinate scan tool implemented in Maestro software, version 10.4. First, the scaffold of the six compounds was manually designed, excluding the alkyl chains. Then, the $360^{\circ}$ coordinate scan was performed using the OPLS 2005 force field in water, incrementing the dihedral angle of $10^{\circ}$.

Generation of Stably Overexpressing AC HEK293 Cells. The plasmid hACpCDNA3.1 containing the human AC variant 1 coding sequence (NM_177924), a N-ter Kozak sequence, and a C-ter His $\operatorname{tag}^{33}$ was modified to remove the C-ter His-tag. It was then used to transfect HEK293 cells using Lipofectamine 2000 (Invitrogen), following the manufacturer's instructions. A stable cell line was generated by selection with $\mathrm{G} 418(1 \mathrm{mg} / \mathrm{mL})$, and cell clones were obtained by limited dilution plating.

AC Activity in Vitro. Clonal HEK293 cells stably expressing AC were used to prepare lysosomal lysates enriched with AC as described, ${ }^{31}$ and AC activity was measured using a fluorogenic assay. ${ }^{50}$ Briefly, $2 \mu \mathrm{g}$ of protein from lysosomal extracts was preincubated with the inhibitors for $30 \mathrm{~min}$ in $25 \mathrm{mM}$ sodium acetate buffer at $\mathrm{pH} 4.5$ at $37^{\circ} \mathrm{C}$. The reaction was started by the addition of the fluorogenic substrate $\mathrm{Rbm}-14-12$ (final concentration in the assay $10 \mu \mathrm{M})$, incubated for $1 \mathrm{~h}$ at $37^{\circ} \mathrm{C}$, and stopped by the addition of methanol and $2.5 \mathrm{mg} / \mathrm{mL}$ of $\mathrm{NaIO}_{4}$ freshly prepared in $100 \mathrm{mM}$ glycine $/ \mathrm{NaOH}$ buffer at $\mathrm{pH} 10.6$. After an additional incubation for 2 $\mathrm{h}$ at $37{ }^{\circ} \mathrm{C}$ in the dark, fluorescence intensity was measured using an Infinite 200 (Tecan) plate reader $\left(\lambda_{\mathrm{ex}} 355 \mathrm{~nm} / \lambda_{\mathrm{em}} 460\right)$. Experiments were performed in triplicate, and $\mathrm{IC}_{50}$ values of $\mathrm{AC}$ inhibition responses were calculated by fitting a four-parameter nonlinear regression model, using GraphPad Prism software V5.03 (GraphPad Software, Inc., USA). Values reported are the mean \pm SD of three independent measurements.

AC Activity in Intact Cells. Melanoma cell lines A375 (ECACC 88113005) and G-361 (ECACC 88030401) were obtained from SIGMA and cultured in Dulbecco's modified Eagle's medium containing $10 \%$ fetal bovine serum and $2 \mathrm{mM}$ L-glutamine in a humidified atmosphere of $5 \% \mathrm{CO}_{2}$ at $37^{\circ} \mathrm{C}$. AC activity was measured using a fluorogenic assay ${ }^{51}$ as described by Morad and collaborators ${ }^{24}$ with minor modifications. Briefly, A375 and G-361 cells $\left(5 \times 10^{4}\right.$ and $2.5 \times 10^{4}$, respectively) were seeded in 96-well plates and $24 \mathrm{~h}$ later treated with compounds or DMSO as control for $2 \mathrm{~h}$ at $37^{\circ} \mathrm{C}$. The fluorogenic substrate dissolved in DMSO was then added to a final concentration of $20 \mu \mathrm{M}$, and the plates incubated for an additional $3 \mathrm{~h}$. Reaction was stopped by the addition of methanol and $\mathrm{NaIO}_{4}$, and fluorescence intensity was measured as described above. Experiments were performed in triplicate, and $\mathrm{IC}_{50}$ values of $\mathrm{AC}$ inhibition responses were calculated by fitting a four-parameter nonlinear regression model, using GraphPad Prism software V5.03 (GraphPad Software, Inc., USA). Values reported are the mean \pm SD of two independent measurements.

Chemical and Mouse Plasma Stability. All compounds were tested for their chemical stability in both neutral buffered solution in $\mathrm{PBS}$ at $\mathrm{pH} 7.4$ and acetate at $\mathrm{pH}$ 4.5. They also were tested for their metabolic stability using mouse plasma. In all cases was monitored the disappearance of compounds by UPLC/MS analysis. Compound stability was evaluated on the basis of the corresponding peak areas plotted versus time. A solution of the same compounds in ACN was also prepared and analyzed in the same conditions and used as 
reference. The compounds' half-lives were calculated using a onephase fitting decay of the peak area vs time profiles.

The following approach and methods were used. Stability in PBS ( $\mathrm{pH}$ 7.4) and acetate ( $\mathrm{pH} 4.5$ ) buffers: compounds from $10 \mathrm{mM}$ stock solutions in DMSO were diluted at $10 \mu \mathrm{M}$ concentration in selected buffer then incubated at $37^{\circ} \mathrm{C}$, and PBS buffer was preheated at $37^{\circ} \mathrm{C}$. Compounds were sampled at different time points $(50 \mu \mathrm{L}$ diluted in $150 \mu \mathrm{L}$ of ACN). Solutions were kept at $37^{\circ} \mathrm{C}$ under shaking. The stability of the compounds was analyzed on a UPLC chromatographic system equipped with BEH C18 reverse phase column $(2.1 \times 50 \mathrm{~mm})$. The compounds were eluted with a linear gradient of $\mathrm{ACN}$ in water from 30 to $100 \%$ in $4 \mathrm{~min}$. Eluted compounds were analyzed in positive ion mode by high-resolution mass spectrometry on a Synapt G2 qTOF mass spectrometer (UPLC, column and qTOF instrument were purchased from Waters, Milford MA, USA).

In vitro mouse plasma stability: compounds were diluted in mouse plasma added with 5\% DMSO to help solubilization. Plasma was already preheated at $37{ }^{\circ} \mathrm{C}(15 \mathrm{~min})$. The final compound concentration was $2.0 \mu \mathrm{M}$. At time points (immediately after dilution, $5,15,30,60$, and $120 \mathrm{~min}$ ), a $30 \mu \mathrm{L}$ aliquot of the incubation solution was diluted in $200 \mu \mathrm{L}$ of cold ACN spiked with Warfarin $200 \mathrm{nM}$, as internal standard. After vortexing for $30 \mathrm{~s}$, the solution was centrifuged at $3500 \mathrm{~g}$ for $15 \mathrm{~min}$ at $4{ }^{\circ} \mathrm{C}$ and the supernatant transferred for LCMS analysis on a Waters Acquity UPLC/MS TQD system.

LC-MS Analysis of Protein Modification. Ten micrograms of recombinant purified human $\mathrm{AC}$ were incubated in $20 \mathrm{mM}$ acetate buffer $+3 \mathrm{mM} \mathrm{DTT}$ for $1 \mathrm{~h}$ at $37^{\circ} \mathrm{C}$ at $\mathrm{pH} 4.5$ (AC enzymatic assay buffer). Analyzed compounds were added in 10:1 molar ratio with the protein and incubated for $1 \mathrm{~h}$ at $37^{\circ} \mathrm{C}$. The reaction was stopped with the addition of cold acetone $\left(4{ }^{\circ} \mathrm{C}\right)$ to the samples $(10 \times$ in volume). After centrifugation for $10 \mathrm{~min}$ at $15000 \mathrm{~g}$ at $4{ }^{\circ} \mathrm{C}$, the supernatant was discarded, and the pellet was dried under a nitrogen stream. $50 \mu \mathrm{L}$ of $50 \mathrm{mM}\left(\mathrm{NH}_{4}\right)_{2} \mathrm{CO}_{3}$ in water $(\mathrm{pH} 8)$ was added to dissolve the pellet. Trypsin (Sigma-Aldrich, Italy) was then added to a final 1:50 trypsin to protein $(\mathrm{w} / \mathrm{w})$ ratio. After an overnight incubation at $37{ }^{\circ} \mathrm{C}$, the resulting peptides were dried and then redissolved in $25 \mu \mathrm{L}$ of $3 \%$ ACN in water added with $0.1 \%$ formic acid. The peptides were analyzed on a UPLC chromatographic system equipped with a BEH C18 reverse phase column $(1 \times 100 \mathrm{~mm})$. The peptides were eluted with a linear gradient of ACN in water (both added with $0.1 \%$ formic acid) from 3 to $50 \%$ in $10 \mathrm{~min}$. Eluted peptides were analyzed in positive ion mode by high resolution tandem mass spectrometry on a Synapt G2 qTOF mass spectrometer (UPLC, column and qTOF instrument were purchased from Waters, Milford MA, USA).

\section{ASSOCIATED CONTENT}

\section{S Supporting Information}

The Supporting Information is available free of charge on the ACS Publications website at DOI: 10.1021/acs.jmedchem.7b00472.

General procedures and spectra (PDF)

Molecular formula strings and additional experimental data $(\mathrm{CSV})$

\section{AUTHOR INFORMATION}

\section{Corresponding Author}

*Phone: +3901071781577. E-mail: Marco.devivo@iit.it.

\section{ORCID $\odot$}

Marco De Vivo: 0000-0003-4022-5661

\section{Present Address}

G.L.S.: BiKi Technologies S.r.l., Via XX Settembre 33, 16121 Genoa, Italy.

\section{Author Contributions}

\#J.A.O. and J.M.A. are equal contributors to this work.

\section{Notes}

The authors declare the following competing financial interest(s): One patent application protecting the class of compounds disclosed in this article has been filed by the following authors: Marco De Vivo, Jose Antonio Ortega and Jose M. Arencibia.

\section{ACKNOWLEDGMENTS}

M.D.V. thanks the Italian Association for Cancer Research (AIRC) ['MFAG n. 14140' and 'IG n. 18883'] for financial support. We thank Grace Fox for copyediting and proofreading the manuscript.

\section{REFERENCES}

(1) Maverakis, E.; Cornelius, L. A.; Bowen, G. M.; Phan, T.; Patel, F. B.; Fitzmaurice, S.; He, Y.; Burrall, B.; Duong, C.; Kloxin, A. M.; Sultani, H.; Wilken, R.; Martinez, S. R.; Patel, F. Metastatic melanoma - a review of current and future treatment options. Acta Derm. Venereol. 2015, 95, 516-524.

(2) Lens, M. B.; Dawes, M. Global perspectives of contemporary epidemiological trends of cutaneous malignant melanoma. Br. J. Dermatol. 2004, 150, 179-185.

(3) Eigentler, T. K.; Caroli, U. M.; Radny, P.; Garbe, C. Palliative therapy of disseminated malignant melanoma: a systematic review of 41 randomised clinical trials. Lancet Oncol. 2003, 4, 748-759.

(4) Flaherty, K. T.; Infante, J. R.; Daud, A.; Gonzalez, R.; Kefford, R. F.; Sosman, J.; Hamid, O.; Schuchter, L.; Cebon, J.; Ibrahim, N.; Kudchadkar, R.; Burris, H. A., 3rd; Falchook, G.; Algazi, A.; Lewis, K.; Long, G. V.; Puzanov, I.; Lebowitz, P.; Singh, A.; Little, S.; Sun, P.; Allred, A.; Ouellet, D.; Kim, K. B.; Patel, K.; Weber, J. Combined BRAF and MEK inhibition in melanoma with BRAF V600 mutations. N. Engl. J. Med. 2012, 367, 1694-1703.

(5) Hodi, F. S.; O’Day, S. J.; McDermott, D. F.; Weber, R. W.; Sosman, J. A.; Haanen, J. B.; Gonzalez, R.; Robert, C.; Schadendorf, D.; Hassel, J. C.; Akerley, W.; van den Eertwegh, A. J.; Lutzky, J.; Lorigan, P.; Vaubel, J. M.; Linette, G. P.; Hogg, D.; Ottensmeier, C. H.; Lebbe, C.; Peschel, C.; Quirt, I.; Clark, J. I.; Wolchok, J. D.; Weber, J. S.; Tian, J.; Yellin, M. J.; Nichol, G. M.; Hoos, A.; Urba, W. J. Improved survival with ipilimumab in patients with metastatic melanoma. N. Engl. J. Med. 2010, 363, 711-723.

(6) Ugurel, S.; Rohmel, J.; Ascierto, P. A.; Flaherty, K. T.; Grob, J. J.; Hauschild, A.; Larkin, J.; Long, G. V.; Lorigan, P.; McArthur, G. A.; Ribas, A.; Robert, C.; Schadendorf, D.; Garbe, C. Survival of patients with advanced metastatic melanoma: The impact of novel therapies. Eur. J. Cancer 2016, 53, 125-134.

(7) Kelderman, S.; Schumacher, T. N.; Haanen, J. B. Acquired and intrinsic resistance in cancer immunotherapy. Mol. Oncol. 2014, 8, $1132-1139$

(8) Jones, C.; Clapton, G.; Zhao, Z.; Barber, B.; Saltman, D.; Corrie, $P$. Unmet clinical needs in the management of advanced melanoma: findings from a survey of oncologists. Eur. J. Cancer Care 2015, 24, $867-872$.

(9) Hyngstrom, J. R.; Chiang, Y. J.; Cromwell, K. D.; Ross, M. I.; Xing, Y.; Mungovan, K. S.; Lee, J. E.; Gershenwald, J. E.; Royal, R. E.; Lucci, A.; Armer, J. M.; Cormier, J. N. Prospective assessment of lymphedema incidence and lymphedema-associated symptoms following lymph node surgery for melanoma. Melanoma Res. 2013, 23, 290297.

(10) Liu, X.; Cheng, J. C.; Turner, L. S.; Elojeimy, S.; Beckham, T. H.; Bielawska, A.; Keane, T. E.; Hannun, Y. A.; Norris, J. S. Acid ceramidase upregulation in prostate cancer: role in tumor development and implications for therapy. Expert Opin. Ther. Targets 2009, 13, 1449-1458.

(11) Bedia, C.; Casas, J.; Andrieu-Abadie, N.; Fabrias, G.; Levade, T. Acid ceramidase expression modulates the sensitivity of A375 melanoma cells to dacarbazine. J. Biol. Chem. 2011, 286, 2820028209. 
(12) Tan, S. F.; Liu, X.; Fox, T. E.; Barth, B. M.; Sharma, A.; Turner, S. D.; Awwad, A.; Dewey, A.; Doi, K.; Spitzer, B.; Shah, M. V.; Morad, S. A.; Desai, D.; Amin, S.; Zhu, J.; Liao, J.; Yun, J.; Kester, M.; Claxton, D. F.; Wang, H. G.; Cabot, M. C.; Schuchman, E. H.; Levine, R. L.; Feith, D. J.; Loughran, T. P., Jr. Acid ceramidase is upregulated in AML and represents a novel therapeutic target. Oncotarget 2016, 7, 83208-83222.

(13) Zeidan, Y. H.; Jenkins, R. W.; Korman, J. B.; Liu, X.; Obeid, L. M.; Norris, J. S.; Hannun, Y. A. Molecular targeting of acid ceramidase: implications to cancer therapy. Curr. Drug Targets 2008, 9, 653-661.

(14) Furuya, H.; Shimizu, Y.; Kawamori, T. Sphingolipids in cancer. Cancer Metastasis Rev. 2011, 30, 567-576.

(15) Coant, N.; Sakamoto, W.; Mao, C.; Hannun, Y. A. Ceramidases, roles in sphingolipid metabolism and in health and disease. Adv. Biol. Regul. 2017, 63, 122-131.

(16) Kartal Yandim, M.; Apohan, E.; Baran, Y. Therapeutic potential of targeting ceramide/glucosylceramide pathway in cancer. Cancer Chemother. Pharmacol. 2013, 71, 13-20.

(17) Ogretmen, B.; Hannun, Y. A. Biologically active sphingolipids in cancer pathogenesis and treatment. Nat. Rev. Cancer 2004, 4, 604616.

(18) Riboni, L.; Campanella, R.; Bassi, R.; Villani, R.; Gaini, S. M.; Martinelli-Boneschi, F.; Viani, P.; Tettamanti, G. Ceramide levels are inversely associated with malignant progression of human glial tumors. Glia 2002, 39, 105-113.

(19) Liu, Y.; He, J.; Xie, X.; Su, G.; Teitz-Tennenbaum, S.; Sabel, M. S.; Lubman, D. M. Serum autoantibody profiling using a natural glycoprotein microarray for the prognosis of early melanoma. $J$. Proteome Res. 2010, 9, 6044-6051.

(20) Mahdy, A. E.; Cheng, J. C.; Li, J.; Elojeimy, S.; Meacham, W. D.; Turner, L. S.; Bai, A.; Gault, C. R.; McPherson, A. S.; Garcia, N.; Beckham, T. H.; Saad, A.; Bielawska, A.; Bielawski, J.; Hannun, Y. A.; Keane, T. E.; Taha, M. I.; Hammouda, H. M.; Norris, J. S.; Liu, X. Acid ceramidase upregulation in prostate cancer cells confers resistance to radiation: AC inhibition, a potential radiosensitizer. Mol. Ther. 2009, 17, 430-438.

(21) Seelan, R. S.; Qian, C.; Yokomizo, A.; Bostwick, D. G.; Smith, D. I.; Liu, W. Human acid ceramidase is overexpressed but not mutated in prostate cancer. Genes, Chromosomes Cancer 2000, 29, 137-146.

(22) Roh, J. L.; Park, J. Y.; Kim, E. H.; Jang, H. J. Targeting acid ceramidase sensitises head and neck cancer to cisplatin. Eur. J. Cancer 2016, 52, 163-172.

(23) Canals, D.; Perry, D. M.; Jenkins, R. W.; Hannun, Y. A. Drug targeting of sphingolipid metabolism: sphingomyelinases and ceramidases. Br. J. Pharmacol. 2011, 163, 694-712.

(24) Morad, S. A.; Tan, S.-F.; Feith, D. J.; Kester, M.; Claxton, D. F.; Loughran, T. P., Jr.; Barth, B. M.; Fox, T. E.; Cabot, M. C. Modification of sphingolipid metabolism by tamoxifen and $\mathrm{N}$ desmethyltamoxifen in acute myelogenous leukemia-Impact on enzyme activity and response to cytotoxics. Biochim. Biophys. Acta, Mol. Cell Biol. Lipids 2015, 1851, 919-928.

(25) Schuchman, E. H. Acid ceramidase and the treatment of ceramide diseases: The expanding role of enzyme replacement therapy. Biochim. Biophys. Acta, Mol. Basis Dis. 2016, 1862, 14591471.

(26) Saied, E. M.; Arenz, C. Small molecule inhibitors of ceramidases. Cell. Physiol. Biochem. 2014, 34, 197-212.

(27) Saied, E. M.; Arenz, C. Inhibitors of ceramidases. Chem. Phys. Lipids 2016, 197, 60-68.

(28) Sugita, M.; Williams, M.; Dulaney, J. T.; Moser, H. W. Ceramidase and ceramide synthesis in human kidney and cerebellum. Description of a new alkaline ceramidase. Biochim. Biophys. Acta, Lipids Lipid Metab. 1975, 398, 125-131.

(29) Bielawska, A.; Linardic, C. M.; Hannun, Y. A. Ceramidemediated biology. Determination of structural and stereospecific requirements through the use of $\mathrm{N}$-acyl-phenylaminoalcohol analogs. J. Biol. Chem. 1992, 267, 18493-18497.
(30) Draper, J. M.; Xia, Z.; Smith, R. A.; Zhuang, Y.; Wang, W.; Smith, C. D. Discovery and evaluation of inhibitors of human ceramidase. Mol. Cancer Ther. 2011, 10, 2052-2061.

(31) Realini, N.; Solorzano, C.; Pagliuca, C.; Pizzirani, D.; Armirotti, A.; Luciani, R.; Costi, M. P.; Bandiera, T.; Piomelli, D. Discovery of highly potent acid ceramidase inhibitors with in vitro tumor chemosensitizing activity. Sci. Rep. 2013, 3, 1035.

(32) Mescic, A.; Harej, A.; Klobucar, M.; Glavac, D.; Cetina, M.; Pavelic, S. K.; Raic-Malic, S. Discovery of new acid ceramidase-targeted acyclic 5-alkynyl and 5-heteroaryl uracil nucleosides. ACS Med. Chem. Lett. 2015, 6, 1150-1155.

(33) Pizzirani, D.; Bach, A.; Realini, N.; Armirotti, A.; Mengatto, L.; Bauer, I.; Girotto, S.; Pagliuca, C.; De Vivo, M.; Summa, M.; Ribeiro, A.; Piomelli, D. Benzoxazolone carboxamides: potent and systemically active inhibitors of intracellular acid ceramidase. Angew. Chem., Int. Ed. 2015, 54, 485-489.

(34) Bach, A.; Pizzirani, D.; Realini, N.; Vozella, V.; Russo, D.; Penna, I.; Melzig, L.; Scarpelli, R.; Piomelli, D. Benzoxazolone carboxamides as potent acid Ceramidase inhibitors: Synthesis and structure-activity relationship (SAR) studies. J. Med. Chem. 2015, 58, 9258-9272.

(35) Kaboudin, B.; Khodamorady, M.; Abedi, Y. A practical and convenient method for the synthesis of some benzimidazoles. Org. Prep. Proced. Int. 2013, 45, 162-167.

(36) Quada, J. C.; Agyin, J. K.; Camden, J. B. Compounds and Methods for Use Thereof in the Treatment of Cancer or Viral Infections. WO 2002026716A2, 2002.

(37) Bahadoor, A.; Castro, A. C.; Chan, L. K.; Keaney, G. F.; Nevalainen, M.; Nevalainen, V.; Peluso, S.; Tibbitts, T. Triazoles as Inhibitors of Fatty Acid Synthase. WO 2011140296A1, 2011.

(38) Fabbrizzi, P.; Menchi, G.; Raspanti, S.; Guarna, A.; Trabocchi, A. Role of side-chain bioisosteres in determining the binding affinity of click chemistry derived RGD peptidomimetics to alpha(v)beta(3) integrin. Eur. J. Org. Chem. 2014, 2014, 7595-7604.

(39) Momoi, T.; Ben-Yoseph, Y.; Nadler, H. L. Substrate-specificities of acid and alkaline ceramidases in fibroblasts from patients with Farber disease and controls. Biochem. J. 1982, 205, 419-425.

(40) Palermo, G.; Campomanes, P.; Neri, M.; Piomelli, D.; Cavalli, A.; Rothlisberger, U.; De Vivo, M. Wagging the tail: essential role of substrate flexibility in FAAH catalysis. J. Chem. Theory Comput. 2013, 9, 1202-1213.

(41) Riccardi, L.; Arencibia, J. M.; Bono, L.; Armirotti, A.; Girotto, S.; De Vivo, M. Lid domain plasticity and lipid flexibility modulate enzyme specificity in human monoacylglycerol lipase. Biochim. Biophys. Acta, Mol. Cell Biol. Lipids 2017, 1862, 441-451.

(42) Palermo, G.; Branduardi, D.; Masetti, M.; Lodoa, A.; Mor, M.; Piomelli, D.; Cavalli, A.; De Vivo, M. Covalent inhibitors of fatty acid amide hydrolase: A rationale for the activity of piperidine and piperazine aryl ureas. J. Med. Chem. 2011, 54, 6612-6623.

(43) Lodola, A.; Branduardi, D.; De Vivo, M.; Capoferri, L.; Mor, M.; Piomelli, D.; Cavalli, A. A catalytic mechanism for cysteine N-terminal nucleophile hydrolases, as revealed by free energy simulations. PLoS One 2012, 7, e32397.

(44) Palermo, G.; Rothlisberger, U.; Cavalli, A.; De Vivo, M. Computational insights into function and inhibition of fatty acid amide hydrolase. Eur. J. Med. Chem. 2015, 91, 15-26.

(45) Pavlin, M.; Rossetti, G.; De Vivo, M.; Carloni, P. Carnosine and homocarnosine degradation mechanisms by the human carnosinase enzyme CN1: Insights from multiscale simulations. Biochemistry 2016, 55, 2772-2784.

(46) Palermo, G.; Campomanes, P.; Cavalli, A.; Rothlisberger, U.; De Vivo, M. Anandamide hydrolysis in FAAH reveals a dual strategy for efficient enzyme-assisted amide bond cleavage via nitrogen inversion. $J$. Phys. Chem. B 2015, 119, 789-801.

(47) Palermo, G.; Bauer, I.; Campomanes, P.; Cavalli, A.; Armirotti, A.; Girotto, S.; Rothlisberger, U.; De Vivo, M. Keys to lipid selection in fatty acid amide hydrolase catalysis: Structural flexibility, gating residues and multiple binding pockets. PLoS Comput. Biol. 2015, 11, e1004231. 
(48) Favia, A. D.; Habrant, D.; Scarpelli, R.; Migliore, M.; Albani, C.; Bertozzi, S. M.; Dionisi, M.; Tarozzo, G.; Piomelli, D.; Cavalli, A.; De Vivo, M. Identification and characterization of carprofen as a multitarget fatty acid amide hydrolase/cyclooxygenase inhibitor. $J$. Med. Chem. 2012, 55, 8807-8826.

(49) Realini, N.; Palese, F.; Pizzirani, D.; Pontis, S.; Basit, A.; Bach, A.; Ganesan, A.; Piomelli, D. Acid ceramidase in melanoma: Expression, localization, and effects of pharmacological inhibtion. J. Biol. Chem. 2016, 291, 2422-34.

(50) Bedia, C.; Camacho, L.; Abad, J. L.; Fabrias, G.; Levade, T. A simple fluorogenic method for determination of acid ceramidase activity and diagnosis of Farber disease. J. Lipid Res. 2010, 51, 35423547.

(51) Bedia, C.; Casas, J.; Garcia, V.; Levade, T.; Fabrias, G. Synthesis of a novel ceramide analogue and its use in a high-throughput fluorogenic assay for ceramidases. ChemBioChem 2007, 8, 642-648. 